\title{
HUMAN RIGHTS IN THE UNITED NATIONS
}

\author{
By Mrres S. MicDougai * and Gereard Bebr **
}

"They meant simply to declare the right, so that enforcement of it might follow as fast as circumstances should permit.

"They meant to set up a standard maxim for free society, which should be familiar to all, and revered by all; constantly looked to, constantly labored for, and even though never perfectly attained, constantly approximated, and thereby constantly spreading and deepening its influence and augmenting the happiness and value of life to all people of all colors everywhere."

\section{-LINCOLN}

The human rights program of the United Nations represents a tremendous collective effort, by the formulation of accepted principle and the establishment of new procedures, to extend protection of basic individual liberties, most broadly conceived, to levels of effective authority higher than the nation state. Rational appraisal of this program would require comprehensive consideration of the goals of the program, the conditions under which these goals are being sought, the inadequacies of traditional international law, the origins and scope of the program, the specific content of proposed United Nations prescriptions, measures of enforcement being proposed and finding acceptance, and experience thus far in the application of new principle. Our exposition here must of necessity be brief and impressionistic. ${ }^{ \pm}$

" Sterling Professor of Law, Yale University School of Law; member of the Board of Editors of this Joondar.

** Formerly Lecturer in Law, Yale University School of Law.

This article expresses only the strictly private views of the authors; in no way does it reflect, interpret, or adrocate any official policy.

The text of this article, with substantially its present content, was first written some twelve years ago for publication in Germany which, because of fortuitous events, did not ensue. Though we have not found it possible fully to canvass changing attitudes and conditions during the past twelve years, we are pleased that the article may now be published in this JouRNaL. Perhaps it is an appropriate commentary upon the slowness of progress with respect to human rights that an artiele prepared so long ago should still be regarded as having some relevance. The text has been modestly updated and given a contemporary documentation by Mr. Bingham Leverich of the 1963-64 International Law Division of the Yale Law School. Dr. Egon Schwelb has assisted with helpful guidance in this revision.

The article is being simultaneously published in German in Die Grundreehte. Handbueh und Theorie der Grundreehte. In Verbindung mit Otto Bachof, Kurt Ballerstedt, Paolo Barile und anderen. Herausgegeben von Karl August Bettermann und Hans Carl Nipperdey. Berlin: Verlag Duncker \& Humblot.

The authors are indebted to the Wenner-Gren Foundation for Anthropological Research for aid in their work.

1 The best comprehensive studies are: Lauterpacht, International Law and Human 


\section{Goals of the United Nations Program}

For its goals the United Nations program is heir to all the great historic movements for man's freedom (including the English, American, and French revolutions and the events they set in train), to the enduring elements in the tradition of natural law and natural rights and in most of the world's great religions and philosophies, and to the findings of contemporary science about the interrelations of simple respect for human dignity and all other individual and community values. ${ }^{2}$ It is familiar history how rudimentary demands for freedom from despotic executive tyranny have gradually been transformed into demands for, and provision of, protection against not only the executive but all institutions or functions of government and even private oppression, and how early demands for the barest "civil liberties," embodied in the most primitive conception of rule by "law," have burgeoned into insistence upon comprehensive "human rights" - that is, into demands for effective participation in all community value processes upon which minimum civil liberties depend." This history can be traced in the changing relation of the individual to the state, from the absolutist state through the liberal or "laissez-faire" state to the emerging conception of political organization as an instrument of all values, with government of, by, and for all people. From demands for physical security and inviolability of the person, with freedom from cruel and inhuman punishment and arbitrary detention, may be noted a progression to demands for freedom of expression and opinion, of conscience and worship, and of meeting and association. ${ }^{5}$ With the impact of industrialization, large-scale concentration of economic power, and urbanization, and the attendant ills of exploitation, unemployment, and inadequate housing, medical care, education, and so on, came not unnaturally demands for

Rights (1950); Jacob Robinson, Human Rights and Fundamental Freedoms in the Charter of the United Nations (1946); Nehemiah Robinson, The Universal Declaration of Human Rights. Its Origin, Significance, Application and Interpretation (2nd ed, 1958); Chakravarti, Human Rights and the United Nations (1958); Ganjii, International Protection of Human Rights (1962). See also: United Nations, Dept. of Public Information, These Rights and Freedoms (1950); United Nations Work for Human Rights (4th ed., 1961), U.N. Pub. Sales No. 62.1.3; A Standard of Achievement (Special 15th Anniversary Edition, 1963), U.N. Pub. Sales No. 62.1.13; Guradze, Dor Stand dor Menschenrechte im Völkerrecht (1956).

2 Lauterpacht, note 1 above, and McDougal, review, 60 Yale Law J. 1051 (1951); Lass. well, World Politics and Personal Insecurity (1935); Arendt, The Origin of Totalitarianism (195I); Dollard and Associates, Frustration and Aggression (1939); Poar (od.), Psychological Factors of Peace and War (1950); Klineberg, Tensions Affecting International Understanding (1950); Cantril (ed.), Tensions That Cause War (1950) (common statement and individual papers by a group of social scientists brought together by UNESCO); Kisker (ed.), World Tension-The Psychopathology of International Relations (1951); Kardiner, The Mark of Oppression (1951).

3 Corwin, Liberty Against Govermment (1948); Barker, Principles of Social and Political Theory 232-233 (1951); Laski, The Rise of European Liberalism 109 (1936).

4 Barker, op. cit. 244-252; Mannheim, Man and Society in an Ago of Reconstruction 336 (1948); Buchanan-Iutz, Rebuilding the World Economy 34 (1947).

5 Corwin, note 3 above; Tawney, Equality (1931). 
improved working and health conditions, fair and adequate wages, access to education and skill aequisition, and protection against the hazards of sickness, unemployment, old age, and the like. ${ }^{\circ}$ Today the recognition is general, and demands are made accordingly, that "liberty" requires "the ordering of social and economic conditions by governmental authority." ?

It is in response to the ever increasing demands of people everywhere for greater access to, and wider sharing of, basic values, of the kind so impressionistically indicated above, that the United Nations program for human rights is being framed and implemented. ${ }^{8}$ For more systematic exposition and appraisal of the specific content of the United Nations formulations, these growing, common demands of people may be conveniently categorized in terms of certain particular values, ${ }^{9}$ as follows:

the wide sharing of power, both formal and effective, including participation in the processes of government and of parties and pressure groups and equality before the law;

the fundamental respect for human dignity which both precludes discriminations based on race, sex, color, religion, political opinion or other ground irrelevant to capacity and provides a positive recognition of common merit as a human being and special merit as an individual; the enlightenment by which rational decisions and other choices can be made, including freedom of inquiry, opinion, and communication;

equal and adequate access to wealth processes, to opportunities for work and to the resources and technology necessary to the production of goods and services for maintaining rising standards of living and comfort;

the opportunity to achieve health and well-being, and the inviolability of the person, with freedom from cruel and inhuman punishments and positive opportunity for the development of talents and enrichment of personality;

opportunity for the aequisition of the skill necessary to express talent and to achieve individual and community values to the fullest;

- Lasswell, "The Interrelations of World Organization and Society," 55 Yale Law J. 889 (1946); Maciver, Democracy and Economic Challenge 29 (1952).

7 Wade, Introduction to Dicey, Law of the Constitution (9th ed., 1950).

8 Former Secretary General Lie, in his address to the New York Herald Tribune Forum, said: "The demand for freedom, for equality of rights, for economic opportunity, can be heard with rising insistence and urgency by all who have ears to hear.

"We faee here one of the great challenges of our eivilization. Either we must find effective ways to answer it by the peaceful evolutionary means proclaimed in the United Nations Charter or we shall find ourselves engulfed in a suceession of violent upheavals that will bring widespread chaos." New York Herald Tribune, Oct. 20, 1952, at p. 10.

o This categorization is derived from Lasswell and Kaplan, Power and Society (1950), and has been used in various previous publications, including MeDougal and Leighton, "The Rights of Man in the World Community: Constitutional Mlusions versus Rational Action," 14 Law and Contemporary Problems 490 (1949), and 59 Yale Law J. 60 (1949); and in AreDougal, "The Comparative Study of Law for Policy Purposes: Value Clarification as an Instrument of Demoeratic World Order," 61 Yale Law J. 917 (1952). Some of these publications are collected in MrCDougal and Associates, Studies in World Public Order (1961). 
opportunity for affection, fraternity, and congenial personal relationships in groups freely chosen;

freedom to choose standards of rectitude and responsibility, to explain life, the universe, and values, and to worship as may seem best; and, in sum, a security which includes not merely freedom from violence and threats of violence, but also full opportunity to preserve and increase all values by peaceful, non-coercive procedures.

Though it is for these values that men have long framed constitutions, established and administered governments, and sought an appropriate formulation of principle and balancing of power, the United Nations program seeks to extend this effort to more people, in a vaster area, at higher levels of authority, and "with a grander vision and on a more comprehensive scale" than bitherto attempted."

\section{Conditions under Which the UnTied Nations Segks Its Gonts}

The conditions under which the United Nations seeks its human rights goals may be described most generally in terms of two trends of contradictory impact: the first and most comprehensive trend is that toward an ever tightening global interdependence of all peoples in securing their basic values, and it is the increasing recognition by peoples of this interdependence that is the dynamic and integrating stimulus behind the human rights program; the interfering trend is that toward the relative bipolarization-or perhaps, more recently, tripolarization-of the world's power structures, which, with its rising crisis in security and continuously more imminent portents of violence, increases the unwillingness of active decision-makers in nation states to loosen controls over individuals and, hence, threatens the whole human rights program, as well as most of man's values and institutions, with disaster.

The major outlines of peoples' contemporary interdependences are only too clear. ${ }^{11}$ More than, 150 years ago Kant wrote:

The intercourse, more or less close which has been steadily increasing between the nations of the earth, has now extended so enormously that a violation of the right in one of the parts of the world is felt all over it.12

Today accelerating changes in technology, in population growth, in the demands and identifications of peoples, and in techniques of organization multiply by many times the intensity of this interdependence. In an earth-space arena of ever increasing dimensions and of hydrogen and atomic bombs, as well, perhaps, as of other new instruments of unimaginable

$10 \mathrm{MeD} o u g a l$ and Leighton, note 9 above.

12 Wright (ed.), The World Community (1948); Ogburn (ed.), Technology and International Relations (1949); Staley, World Economy in Transition 3-56 (1939); Lasswell, "The Interrelations of World Organization and Society," 55 Yalo Law J. 889 (1946); Bourquin, "Pouvoir Scientifique et Droit International," 70 Hague Academy Recueil des Cours 335-402 (1947).

12 Kant, Perpetual Peace 142 (Smith ed., 1917). 
destructiveness, it needs little emphasis that no people can be secureeven in the minimal sense of freedom from violence and threats of violence -unless all peoples are secure. It is scarcely less obvious that security, even in this minimal sense, is dependent upon the abundant production and wide sharing of all other values: upon, in terms of the categorizations suggested above, a sharing of power which does not repress and accumulate hatreds but gives outlet to constructive energies; upon a respect for human dignity which does not breed psychopathic personalities, resentments, and predispositions to violence, but rather gives ample opportunity for the fullest development of personality and creative capacity; upon a flow of enlightenment which facilitates realistic orientation in contemporary world processes and the making of decisions which rationally promote major objectives; upon the production and distribution of the goods and services necessary to maintain continually rising standards of living and the provision of ample opportunities for employment on respected jobs; upon maintenance of standards of health and well-being and protection of the person which permit the fullest and freest participation in all value processes; upon continually widening positive identifications of peoples with peoples and intensifying loyalties to larger areal groupings; and, finally, upon sufficient consensus in conceptions of right and wrong to support appropriate institutions and a growing sense of common responsibility, whatever the details of justification, for preservation and enhancement of the values of all peoples. Conversely, whatever values we summarize as "human rights," however narrowly or broadly we may conceive them, are with equal obriousness dependent upon "security" and all other values." Most broadly and rationally conceived, the "human rights" and "security" of any people and all peoples may in fact be said to be not merely "interdependent" but identical; the different words are but alternative ways of describing the same aspirations and interrelations of people.

It is not, however, rational co-operation in the peaceful pursuit of interdependent values, but rather the trend toward bipolarization or tripolarization, and contending systems of public order with nation states organizing themselves into "garrisoned camps," that today most conspicuously dominate the world arena. The growth of great power bloes, with several of the dominant Powers insisting upon the inevitability of world dominion by totalitarian measures, the destructive potentialities of

15 These interdependences are outlined in more detail in McDougal and Leighton, note 9 abore, and MeDougal, "The Role of Law in World Politics," 20 Miss. Law J. 253 (1949). See also Klineberg, Tensions Affecting International Understanding 187212; Horkheimex, "The Lessons of Faseism," in Cantril (ed.), Tensions That Cause Wars 209-242; Kisker, World Tension-The Psychopathology of International Relations 312; Lasswell, "World Loyalty," in Wright (ed.), The World Community 200-225; Gorove, "Towards World Loyalty," 23 Miss. Law J. 159-188 (1952); Flugel, Man, Morals and Soeiety 316-317 (1945); West, Conscience and Society 226-237 (1945); "A Plea For Rational Approach to the Problem of War and Peace," 16 U. of Chicago Law Rev. 390-396 (1948/49). 
the newly developed weapons, and the continued incidence in many parts of the world of ignorance, disease, poverty, and exploitation, with their attendant political instabilities, all combine to create general expectations of rising insecurities and more comprehensive violence. These expectations of imminent violence both increase the ordinary diffeulties in co-operation between nation states and facilitate processes within nation states deeply inimical to human rights. As lines between probable combatants are more and more sharply drawn, proposals for co-operation between nation states for the promotion of "human rights" or "security" or any other value are appraised in terms, not of possible long-range effects in an ever receding peaceful world, but rather of immediate impact on fighting effectiveness. Within nation states, measures considered indispensable to security in a bipolar world of impending atomic war, whether rationally calculated or not, tend to move even the freer societies toward practices resembling those of the totalitarianism they fight. ${ }^{14}$ The whole global transformation has been aptly described as a movement toward "garrison-police" states, in which demands for power are accentuated at the expense of every other value, with increasing militarization, governmentalization, centralization, concentration, and regimentation, and in which all values other than power are "politicized" in such practices as "the compulsion to work" and the gradation and stabilization of income, the "requisitioning of talent and skill," the "administration of hate" and "withdrawal of affection," the "requisitioning of loyalty," the "dogmatization and ritualization" of rectitude, and so on. ${ }^{15}$ In this context it is small wonder that the United Nations' human rights program exhibits some of the symptoms of incipient paralysis.

\section{The Inadequacies of Tradmionar Internationat Law}

The failure of traditional international law to develop doctrines and procedures for protecting the fundamental rights of the individual has been many times recounted. The sum of the story is that under the impact of nineteenth-century positivistic notions, antithetical to the premises of the great founders of international law, who addressed their prescriptions to "sovereigns" and "subjects," 16 that only nation states were the appropriate "subjects" of international law, it became respected dogma that the relations between a nation state and its members-"subjects" or "nationals" or "citizens"-was a matter of internal or "domestic" concern only and, hence, beyond the reach of international law..37 Exceptions or:

14 Lasswell, National Security and Individual Freedom (1950).

15 This description is that of Lasswell in The World Revolution of Our Timo (1951). See also his National Security and Individual Freedom (1950); "Inevitable War'": A Problem in the Control of Long Range Expectations," 2 World Politics 1-40 (1949); and "The Prospects of Cooperation in a Bi-polar World," $15 \mathrm{U}$. of Chicago Law Rev. 887-901 (1947/48).

16 Corbett, Law and Society in the Relations of States 54 (1951); Idelson, "The Law of the Nations and the Individual," 30 Grotius Society Transactions 50 (1944). 17 Hyde, International Law Chiefly as Interpreted and Applied by the United States 
qualifications were, of course, admitted. Should the active decision-makers in a nation state abuse members too much, "humanitarian intervention" might become legal. This doctrine has been authoritatively, if optimistically, summarized as prescribing that

each state has a legal duty to see that conditions prevailing within its own territory do not menace international peace and order, and to this end it must treat its own population in a way which will not violate the dictates of humanity and justice or shock the conscience of mankind

and is alleged to "require of each state a minimum protection" of "all inhabitants of its territory." 18 Nation states have, furthermore, by special agreement often assumed obligation to treat their members in accord with stipulated standards of human decency.19 Notable instances that may be recalled include early agreements among the Christian European states and with the Mohammedan rulers for religious freedom, agreements for repressing slavery and the slave trade and for promoting humane conditions of labor, agreements for preventing white slavery and for policing the opium trade, the "minorities treaties" after World War I, and the general provisions in the peace treaties concluded since World War II for the protection both of minorities and of others. ${ }^{20}$ Sporadic exceptions to negative doctrine and occasional agreements, poorly implemented, obviously do not, however, add up to the comprehensive and effective protection of the members of nation states against oppression by elites from within their nation states.

For "aliens"-that is, individuals regarded as members of one nation state but caught in the territorial jurisdiction of another-international law has, in curious contrast, developed somewhat more extensive protection. ${ }^{21}$ The standard by which this protection is to be measured is still,

209 (1945); Oppenheim, International Law 279 (Lauterpacht, 7th ed., 1948). Kunz, "Present-Day Efforts at International Protection of Human Rights: A General Analytical and Critical Introduction," 1951 Proceedings, American Society of International Law 117, still maintains that "to make individuals direct subjects of international law... has no chance to be realized, for theoretical as well as practical reasons.",

18 "The International Law of the Future," 30 Am. Bar Assn. Journal 35-37 (1944); 38 A.J.I.I. Supp. 54-135 (1944). See also Oppenheim, note 17 above.

10 Jessup, A Modern Law of Nations 88 (1948); Fenwick, Iriternational Law 265 (3rd ed., 1948).

20 Consultative Council of Jewish Organizations, Implementation of an International Corenant of Human Rights 27 (1952); Arts. 15 and 19, par. 4, Italian Peace Treaty; Art. 2, Hungarian and Bulgarian Peace Treaties, and Art. 3, Rumanian Peace Treaty. Full text, Dept. of State, Treaties of Peace ... (Pub. 2743, European Series 21); 42 A.J.I.L. Supp. 47, 179, 225, 252 (1948) ; Martin, "Fuman Rights in the Paris Peace Treaties," 24 Brit. Yr. Bk. Int. Law 392-398 (1947); Kertesz, "Human Rights in Peace Treaties," 14 Law and Contemporary Problems 627-646 (1949). See also Sehwelb, "The Austrian State Treaty and Human Rights," 5 Int. and Comp. Law Q. 265 (1956).

21 Roth, Minimum Standard of International Law Applied to Aliens 23 (1949); Dunn, The Protection of Nationals 47 (1931). 
however, a subject of bitter dispute, and the procedures for making effective the protection, whatever the standard, are still most inadequate. A majority perhaps of nation states insist that there is an "international standard of civilized justice," transcending all local peculiarities and inadequacies, with which the decision-makers in nation states must comply in protecting aliens. ${ }^{22}$ But a vigorous minority continues to assert that the only international standard is that of "equality of treatment," that aliens will be treated no worse than members-a standard which may offer small protection indeed. ${ }^{23}$ For securing redress, an injured or deprived alien, or his representative, furthermore, is not given access to national or international fora as an individual, but is rather required to turn to the nation state that accepts him as a member for intervention through normal diplomatic channels. The fiction is that the wrong done the individual is a wrong done his nation state, and international law imposes no duty on the nation state to prosecute his claim, leaving any action to unfettered official discretion and considerations of political or other expediencies. ${ }^{24}$ The inadequacies of the whole structure of doctrine and practice for protecting the fundamental human rights of individuals become even more apparent when it is added that not even this meager protection is available to stateless persons, persons of double nationality when both nation states are involved, and persons who are members of an unrecognized nation state. ${ }^{25}$

It may perhaps require emphasis, to forestall possible over-estimation of the degree of innovation in the United Nations program, that the notion underlying the common rationalizations of the doctrines and practices outlined above, that the individual human being is not an appropriate "subject" of international law, is but a doctrinal half-truth, sometimes accepted and sometimes rejected. An opposing tradition has always recognized the individual as the ultimate beneficiary of all the doctrines and practices of international law, ${ }^{26}$ and in relatively recent times has succeeded in

For a detailed discussion, see Harvard Law School, Research in International Law, the Law of Responsibility of States for Damage Done in Their Territory to the Porson or Property of Foreigners, 23 A.J.I.I. Spec. Supp. 133-218 (1929); Borchard, Tho Diplomatic Protection of Citizens Abroad (1919). The recent discussions in tho International Law Commission offer a great variety in view.

22 Borchard, cited above, Preface; Dunn, cited above, pp. 62-63; Roth, cited above, pp. 81-110; Borchard, "The Minimum Standard of the Treatment of Aliens," 1039 Proceedings, Am. Soc. Int. Law 51-63.

23 Dunn, cited above, pp. 56, 140-141; Roth, above, pp. 62-80.

24 Freeman, "Human Rights and the Rights of Aliens," 1951 Proceedings, Am. Soc. Int. Law 127.

25 Ibid. 123, 127. See, however, the Statute of the Office of the United Nations High Commissioner for Refugees, annexed to General Assembly Res, 427/V/1950; Convention on the Status of Refugees, 1951, eited in note 46 below; and the Convention on the Status of Stateless Persons, 1954, U.N. Conference on the Status of Stateless Persons, Final Act and Compention, U.N. Doc. E/CONF.17/5/Rer.I., and 1954 Yearbook of Human Rights 369.

26 Lauterpacht, International $L a w$ and Human Rights 78-79 (1950); Vordross, Völkerrecht 492-493 (1950); Schindler, "Gedankon zum Wiederaufbau des Völkorrechts," in his Recht, Staat und Völkergemeinschaft 237, 239, 240 (1948); Politis, 
securing for him direct access to international fora of various kinds for the protection of many special interests. ${ }^{27}$ Similarly, rational effort to achieve and maintain effective sanctions has long subjected the individual, unshielded by his nation state, directly to duties under international lawmost notably with respect to the laws of war, neutrality, and piracy, and under agreements with respect to slave trading, counterfeiting, fisheries, arms smuggling, and so on. ${ }^{28}$ In terms of realistic description, it is obvious that the individual human being-both as a player of rôles in such institutions as the nation state, international governmental organizations, political parties, pressure groups, and private associations, and as a person whose loyalties and choices may transcend any particular rôle or combination of rôles-is an effective participant in the world power process. Not all traditional international law precludes recognition in formal doctrine and authoritative decision of this reality. ${ }^{29}$

\section{The Ortains and Scope of the United Nations Programi}

International co-operation in the days of the League of Nations produced no comprehensive program for the protection of human rights. The emphasis in President Wilson's Fourteen Points, ${ }^{30}$ in the 1919 Peace Treaties, and in the "Minorities Treaties" was not upon the rights of individuals but upon the rights of nations and of minority groups within

The New Aspect of International Law 24-25 (1928). See also O'Sullivan, “The Concern of International Law for the Individual," 34 Grotius Society Transactions 6-29 (1948); Dunn, "The International Rights of the Individual," 1941 Proceedings, Am. Sac. Int. Iraw 18; MreDougal, "International Law, Power and Policy: A Contemporary Conception," 82 Hague Academy Recueil des Cours 173, 174, 237-256 (1953).

27 Hambro, "Individuals before International Tribunals," 1941 Proceedings, Am. Soe. Int. Law 22-27; Lauterpacht, cited above, p. 48. See also explanatory paper on measures of implementation prepared by the Secretary General, U.N. Doc.A/5411 (April, 1963).

28 Lauterpacht, note 1 above, p. 38 et seq.; Levy, "Criminal Responsibility of Individuals and International Law," $12 \mathrm{U}$. of Chicago Law Rev. 313, 326 (1945); MICDougal and Feliciano, Law and Mlinimum World Public Order 706 (1961).

Art. II of the Convention for the Protection of Submarine Telegraph Cables, 75 Brit. and For. State Papers 356 (1883-1884); North Sea Convention, 79 ibid. 894 (1887-1888); Convention for Unification of Certain Rules of Law with Respect to Assistance and Salrage at Sea, 3 U. S. Treaties 2943 (1923); Convention for Preservation and Protection of Fur Seals, ibid. 2966; Convention on the Suppression of Counterfeiting Currency, 4 Hudson, International Legislation 2692 (1928-1929); Convention Between the U. S. and Other Powers to Suppress Slave Trade and Slavery, 4 U. S. Treaties 5022 (1938); Convention on the Suppression of Traffic in Women and Children, 1 Hudson, International Legislation 726 (1919-1921); Convention For Limiting the Manufacture and Regulating the Distribution of Narcotics, 139 L. N. Treaty Series 301. See also the decision of the U. S. Consular Court in Tangier on a piracy charge, New York Times, Dec. 21, 1952, p. 1, col. 1.

20 Lauterpacht, "The Subjects of the Law of Nations," 64 Law Quarterly Rev. 97, 99 (1948); Wright, "International Law and Power Polities," 2 Measure 135 (1951).

30 Message to the Congress, Jan. 18, 1918, 56 Cong. Rec., Pt. I, p. 651, 65th Cong., 2nd Sess.; reprinted in 13 A.J.I.L. 161 (1919). 
nations. ${ }^{31}$ The principal emphasis upon the rights of individuals was in the Japanese proposal to the Peace Conference, a proposal subsequently rejected, for equality of treatment of aliens. ${ }^{32}$ An elementary international protection to individuals was offered by the Minority Treaties-especially the important German-Polish Convention concerning Upper Silesia ${ }^{\text {sa }}$ but this protection was achieved only through identification with a national minority group.

Stimulated by the mounting evidences of a new barbarism and by the need to clarify war aims, Allied official pronouncements and declarations began, however, early in World War II unmistakably to emphasize the individual and his rights. In his famous "Four Freedoms" speech to the United States Congress on January 6, 1941,,34 President Roosevelt included freedom from want and freedom from fear, along with freedoms of expression and of worship, in "four essential human freedoms" upon which world order should be founded, and his broad conception of human liberties was later confirmed, in the Atlantic Charter and in the Declaration by the United Nations, as embodying specific war and peace aims. ${ }^{35}$ The Dumbarton Oaks Proposals included among the purposes of the projected organization "international cooperation in the solution of international economic, social, and other humanitarian problems" and, at the instance of the United States, promotion of "respect for human rights and fundamental freedoms." 36 At the San Francisco Conference these modest beginnings were transformed into the various human rights provisions which today constitute so important and so conspicuous a part of the United Nations Charter.

The United Nations Charter explicitly recognizes that the maintenance of "international peace and security" and the protection of human rights are today interdependent, if not identical, purposes; announces the promotion of human rights as one of the major aims of the new organization; and imposes upon both Member states and the organization a clear legal obligation to promote the increased protection of human rights. This structure of purpose and obligation is outlined in various provisions of the Charter. In the Preamble, the "peoples of the United Nations," not merely the Member states, reaffirm their "faith in fundamental human rights" and "in the dignity and worth of the human person." Article 1 includes among stated purposes the achievement of

31 Jones, "National Minorities: A Case Study in International Protection," 14 Law and Contemporary Problems 599 (1949); Mitrany, "Human Rights and International Organization,' 3 India Q. 115 (1947).

321 Miller, The Drafting of the Covenant 183 (1928); see also pp. 269, 461.

33 Kreckenbeeck, The International Experiment of Upper Silesia (1942).

3487 Cong. Rec., Pt. I, pp. 46-47, 77th Cong., 1st Sess.

356 Dept. of State Bulletin 3 (1942); 35 A.J.I.L. Supp. 191 (1941); 36 ibid. 191 (1942).

36 Dept. of State, Postwar Foreign Policy Preparation 1939-1945, p. 327 (Pub. 3580, Gen. Foreign Pol. Series 15, 1950). For the Dept. of State's preliminary work and drafting of a "Bill of Rights" see ibid. 84, 98, 115-116; for the test of the draft, see ibid. 483-485, Annex No. 14. 
international cooperation in solving international problems of an economic, social, cultural, or humanitarian character, and in promoting and encouraging respect for human rights and for fundamental freedoms for all without distinction as to race, sex, language, or religion.

Article 13 orders the General Assembly to "initiate studies and make recommendations" for the purpose of

promoting international cooperation in the economic, social, cultural, educational, and health fields, and assisting in the realization of human rights and fundamental freedoms for all without distinetion as to race, sex, language or opinion.

Article 55, seeking "the ereation of conditions of stability and well-being which are necessary for peaceful and friendly relations among nations," includes among the purposes of "international economic and social cooperation" the promotion of "universal respect for, and observance of, human rights and fundamental freedoms for all without distinction as to race, sex, language, or religion"; and in Article 56

All Members pledge themselves to take joint and separate action in cooperation with the organization for the achievement of the purposes set forth in Article 55.

Article 62 empowers the Economic and Social Council to "make recommendations for the purpose of promoting respect for, and observance of, human rights and fundamental freedoms for all," and Article 68 orders the Council to "set up commissions in economic and social fields and for the promotion of human rights." Article 76 stipulates that "basic objectives" of the international trusteeship system are, inter alia, "to encourage respect for human rights and for fundamental freedoms for all" and, it is worth note, "to encourage recognition of the interdependence of the peoples of the world." Though human rights and fundamental freedoms are nowhere in the Charter more explicitly defined than in these quoted provisions, both immediate legal obligations and a continuous program of definition and implementation seem clearly contemplated. In his closing address to the San Franciseo Conference, President Truman summarized common expectations :

Under this document [the Charter] we have good reason to expect an international bill of rights acceptable to all the nations involved. That Bill of Rights will be as much a part of international life as our own Bill of Rights is part of our Constitution. The Charter is dedicated to the achievement and observance of human rights and fundamental freedoms. Unless we can attain those objectives for all men and women everywhere - without regard to race, language, or religionwe cannot have permanent peace and security in the world. ${ }^{37}$

371 U.N.C.I.O. Does. 717 (1945). Art. $2(7)$ of the United Nations Charter, which recites that "nothing contained in the present Charter shall authorize the United Nations to intervene in matters which are essentially within the domestic jurisdiction of any state or shall require the Members to submit such matters to settlement under the present Charter," has been on occasion invoked as imposing limitation on the powers both of nation states to make new agreements and of the U.N. Organization 
The first major implementation of the Charter provisions came with the Universal Declaration of Human Rights, drafted after two years of study by the Commission on Human Rights established under Article 68 of the Charter by the Economic and Social Council, and approved, without dissenting vote, by the General Assembly on December 10, 1948.88 This Declaration was not designed or proposed as an enforceable treaty obligation, but rather as a broad clarification and recommendation of policy. It was intended, as the General Assembly proclaimed it,

as a common standard of achievement for all peoples and all nations, to the end that every individual and every organ of society, keeping this Declaration constantly in mind, shall strive by teaching and education to promote respect for these rights and freedoms and by progressive measures, national and international, to secure their universal and effective recognition and observance, both among the peoples of member states themselves and among the peoples of territories under their jurisdiction. ${ }^{30}$

The rights stipulated in the Declaration are most comprehensive. They include, among many items, not only provision for equality of treatment with respect to all rights and freedoms set forth in the Declaration, "without distinetion of any kind, such as race, colour, sex, language, religion, political or other opinion, national or social origin, property, birth or other status," and the traditional personal liberties such as freedom and security of person, right to a fair trial, and freedom of thought, expression, opinion, religion, assembly, association, and movement, but also certain more recently emerging political, economic, and social claims, such as those to nationality and freedom to change nationality, to asylum from persecution, to take part in government and to have equal access to public service, to social security and choice of employment, and to education, leisure, participation in cultural life, and an adequate standard of living. Despite its lack of status as enforceable treaty obligation or even as "authoritative interpretation" of such obligation, and despite the imprecision of some of its language, ${ }^{40}$ this Declaration has, because of its authoritative community origin and eloquent formulation of the growing common demands of peoples

to undertake programs of definition and implementation with respect to human rights. It seems elear, however, that this article imposes no limitation on the powers of nation states to make new agreements and little, if any, limitation on the powors of the organization in the domain of human rights. The words "domestic jurisdiction" have no inherent or established doctrinal meaning and were purposely left vague in tho Charter to enable the organization effectively to meet unknowable future contingencies. The explicit stipulations in the Charter for promoting human rights would have been meaningless had it been intended that the "domestic jurisdiction" clause should pro. clude definition and implementation. See MeDougal and Leighton, noto 9 above, at 77, and Lauterpacht, note 1 above, at 166 .

38 For the text of the Declaration, see Res. 217 (III) in General Assembly, 3rd Bess., Official Records, Pt. I, Resolutions, p. 71; 43 A.J.I.I. Supp. 127 (1949).

39 Ibid.

10 Lauterpacht, note 1 above, pp. 394-408; Fawcett, "A British View of tho Covo. nant," 14 Law and Contemporary Problems 439 (1949); Ch. Malik, "Progress of the Covenant on Eluman Rights," 10 United Nations Bulletin 554-557 (1951). 
throughout the world, exercised an important influence on subsequent decision-making and prescribing in many world arenas. ${ }^{41}$ Its future influence may, because of the increasing importance of General Assembly resolutions as a source of customary law, be even greater.

The Genocide Convention, drafted by a special ad hoc committee and revised and approved by the General Assembly on December 9, 1948,42 should also perhaps be regarded as a measure in implementation of the human rights provisions of the Charter. This convention was designed as enforceable treaty obligation after 20 ratifications, and became operative on January 12, 1951, though the major Powers have been slow to ratify. Framed to complement the Nuremberg verdict, which restricted "crimes against humanity" to "inhumane acts, in connection with the planning or waging of aggressive war," 43 the Genocide Convention makes the intentional destruction "in whole or part" of "a national, ethnical, racial, or religious group as such" an international crime. Acts which constitute genocide include "killing members of the group," "causing serious bodily or mental harm to members of the group," "deliberately infllicting on the group conditions of life caleulated to bring about its physical destruction in whole or in part," "imposing measures intended to prevent births within the group," and "forcibly transferring children of the group to another group." Not only genocide but also "conspiracy to commit genocide," "direct and public incitement to commit genocide," "attempt to commit genocide," and "complicity in genocide" are made punishable. Constitutional rulers and public officials as well as private individuals are made responsible. ${ }^{44}$ For enforcement, the contracting parties undertake to enact

41 See Schwelb, "The Influence of the Universal Declaration of Human Rights on International and National Law," 1959 Proceedings, Am. Soc. Int. Law 217, and "Die Kodifikationsarbeiten der Vereinten Nationen auf dem Gebiete der Menschenrechte," 8 Archiv des Völkerrechts 16, 36 (1959); Lin Mousheng, "The Human Rights Program," in 1961-1962 Annual Review of United Nations Affairs 102, 105 (1963); A Standard of Achierement, op. cit. note 1 above, at 12-32; Sehwelb, Human Rights and the International Community (1964).

42 Res. 260 (III); General Assembly, 3rd Sess., Official Records, Pt. I, Resolutions, p. 174; 45 A.J.I.L. Supp. 7 (1951). It should be noted that Arts. 2 and 3 of the convention mole constitutional rulers and officials responsible for acts committed against their own eitizens. As of June, 1962, the convention had been ratified or aceeded to by 64 states.

43 Office of United States Chief of Counsel of Prosecution of Axis Criminality, Nazi Conspiracy and Aggression, Opinion and Judgment (1947); 41 A.J.I.L. 172 (1947). The Nuremberg Judgment marks a full recognition of the international responsibility of the individual and affirms a realistic principle of international law. "Crimes against international law are committed by men, not by abstract entities, and only by punishing individuals who commit such crimes can the provisions of international law be enforeed." International Military Tribunal Judgment, Sept. 30, 1946. See I Trial of the Major War Criminals 222-223 (1947); Schwelb, "Crimes Against Humanity," 23 Brit. Yr. Bk. Int. Law 178-226 (1946); MIcDougal and Feliciano, op. cit. note 28 above, at 126 and 165 .

$44 C f$. Art. IV of the Genocide Convention. See also Art. 25 of the draft statute for an international criminal court: "The Court shall be competent to judge natural persons, whether they are constitutionally responsible rulers, public officials or private indi- 
necessary domestic legislation and to provide effective penalties, with trial before

a competent tribunal of the State in the territory of which the act was committed, or by such international penal tribunal as may have jurisdiction with respect to those Contracting Parties which shall have accepted its jurisdiction.

Disputes as to "interpretation, application, or fulfillment" of the convention are to be referred to the International Court of Justice.

Numerous other measures in implementation of the human rights provisions of the Charter have been completed under the auspices of the United Nations and its specialized agencies. ${ }^{45}$ The problem of statelessness and the status of refugees and stateless persons has been treated in the Convention Relating to the Status of Refugees of $1951,{ }^{46}$ the Convention Relating to the Status of Stateless Persons of 1954, ${ }^{47}$ and the more recent Convention on the Reduction of Statelessness of $1961 . .^{48}$ In the area of labor law, protection of trade union rights and freedom of association, as well as protection against forced labor, slavery, and servitude is afforded by the Convention Concerning Freedom of Association and Protection of the Right to Organize of $1948,{ }^{49}$ the Convention Concerning the Application of the Principles of the Right to Organize and to Bargain Collectively of $19492^{50}$ the Supplementary Convention on the Abolition of Slavery, the

viduals." Report of the Committee on International Criminal Jurisdiction, Gonornl Assembly, 9th Sess., Official Records, Supp. No. 12 (A/2645) (1953).

45 For more detailed discussion of these measures, see Schwelb, "International Con. ventions on Human Rights," 9 Int. and Comp. Law Q. 654 (1960); United Nations Work for Human Rights, op. oit. note 1 above, at 12-35.

40 For text see Final Act and Convention Relating to the Status of Rofugees, U.N. Doc. A/CONF. 2/108/Rev. 1, U.N. Pub. Sales No. 1951. IV.4; 11 U.N. Bullotin 143148 (1951); 1951 Yearbook on Human Rights 581. As of June, 1962, the convention had been ratified or acceded to by 33 states. See also Weis, "The International Protection of Refugees," 48 A.J.I.I. 193 (1954).

47 For text see Final Act and Convention Relating to the Status of Stateloss Persons, U.N. Doc. E/CONF. 17/5/Rev. 1, U.N. Pub. Sales No. 1956. XIV.1; 1954 Yearbook on Eluman Rights 369. As of June, 1962, the convention had been ratified or acceded to by 11 states. Note that stateless persons are granted merely treatmont "not less favorable" than that accorded to aliens generally in the matter of wage. earning employment (Art. 17) and the right of association (Art. 15), whoreas rofugeos are entitled to "the most farourable treatment accorded to nationals of a foroign country, in the same circumstances." (Convention Relating to the Status of Rofugeos, note 46 above, Arts. 17 and 15.)

18 For text see Final Act and Convention on the Reduction of Statelessmess, U.N. Docs, A/CONF. 9/14 and A/CONF. 9/15.

40 For text see U.N. Dept. of Public Information, These Rights and Freedoms 192197 (1950); 1948 Yearbook on Human Rights 427. As of June, 1962, the convention had been ratified or acceded to by 58 states. See also Jenks, The International Proteetion of Trade Union Freedom 24 (1957).

50 For text see These Rights and Freedoms, cited above, pp. 198-202; 1949 Yonrbook on Human Rights 291. As of June, 1962, the convention had been ratified or acceded to by 53 states. See also Jenks, note 49 above, and "The Application of International 
Slave Trade, and Institutions and Practices Similar to Slavery of 1956,51 and the Convention Concerning the Abolition of Forced Labor of $1957 .^{52}$ The right of freedom of information, though a subject on which Member states have had considerable difficulty in reaching agreement, has nevertheless found some expression in the Convention on the International Right of Correction of $1952,{ }^{53}$ the Draft Convention on the Gathering and International Transmission of News of 1949,54 and the Draft Convention on Freedom of Information. ${ }^{\text {vo }}$

The goal of prevention of discrimination and the protection of minorities, a subject which is currently being systematically studied by a subcommission of the Commission on Human Rights, has so far been given authoritative sanction only in the limited prescription in the Convention and Recommendation Concerning Discrimination in Respect of Employment

Labour Conventions by Means of Collective Agreements," 19 Zeitschrift für Auslïndisches öffentliches Recht und Völkerrecht 197-224 (1958).

01 For text see Final Act of the U.N. Conference of Plenipotentiaries on a Supplementary Convention on the Abolition of Slavery, the Slave Trade, and Institutions and Practices Similar to Slavery, U.N. Doc. E/CONF. 24/23, U.N. Pub. Sales No. 1957. XIV.2; 1956 Yearbook on Human Rights 289. As of June, 1962, the convention had been ratified or aceeded to by 38 states.

E2 For text see International Labour Office, Official Bulletin, Vol. XI (1957), No. 1; Appendix XVI to the Record of Proceedings of the International Labour Conference, 40th Sess., Genera, 1957; 1957 Yearbook on Human Rights 303. As of June, 1962, the convention had been ratified or aceeded to by 54 states. See also Jenks, Human Rights and International Labour Standards (1960).

53 For text see General Assembly, Res. 630 (VII), 7th Sess., Official Records, Supp. No. 20 (A/2361), p. 22; 1952 Yearbook on Human Rights 373. As of Dec. 31, 1962, the convention had been ratified or aceeded to by 7 states, and henee had come into force.

54 The text of the Draft Convention on the Gathering and International Transmission of News had been amalgamated with the original Draft Convention Coneerning the Institution of an International Right of Correction in 1949 to form the Draft Convention on the International Transmission of News and the Right of Correction, which was approved by the General Assembly (Res. 277 C (III)). The General Assembly, however, also adopted a resolution providing that the amalgamated draft convention shall not be open for signature until the General Assembly has taken definite action on the Draft Convention on Freedom of Information (Res. 277 A (III)). For text of the amalgamated Draft Convention, see 1949 Yearbook on Human Rights 356; General Assembly, Res. 277 (III), 3rd Sess., Official Records, Pt. II, Resolutions, pp. 21-30 (1949). In 1952 the provisions on the right of correction were taken out again. See note 53 above.

vo For revised draft of the convention now before the General Assembly, see U.N. Doc. A/AC.42/7. At the 14th, 15th and 16th sessions of the General Assembly (1959, 1960, 1961) the Third Committee revised the Preamble and Arts. 1 to 4 of the draft convention. See the Reports of the Third Committee, U.N. Docs. A/4341, A/4636 and A/5041. At its 1962 session, the General Assembly resolved to give priority to the draft convention and declaration on freedom of information (Res. 1840 (XVII)). Other instruments which might also be mentioned as implementing the goal of freedom of information include the following: Agreement for Facilitating the International Cireulation of Visual and Auditory Mraterials of an Educational, Scientific, and Cultural Character, 1948 Yearbook on Human Rights 431; Agreement on the Importation of Educational, Scientific, and Cultural Materials, 1950 ibid. 411; The International Telecommunication Convention, 1947 United Nations Yearbook 932. 
and Occupation of $1958,{ }^{58}$ and the Convention and Recommendation against Discrimination in Education of 1960.57 The status of women, on the other hand, has been quite extensively treated in the Convention Concerning Equal Remuneration for Men and Women Workers for Work of Equal Value of 1951,58 the Convention on the Political Rights of Women of 1952,00 the Convention on the Nationality of Married Women of $1957,{ }^{\circ 0}$ and the recent Convention on Consent to Marriage, Minimum Age for Marriage, and Registration of Marriages of 1962. ${ }^{\text {B1 }}$ In recent years, governments have turned again to the use of declarations when the method of international treaties has proved practically impossible; witness the United Nations draft Declarations on the Right of Asylum, ${ }^{62}$ on Freedom of Information, ${ }^{03}$ and

56 For text see International Labour Conference, 42nd Sess., Geneva, 1958, Records of Proceedings, p. 834, Convention No. 111; 1958 Yearbook on Human Rights 307. As of June, 1962, the convention had been ratified or acceded to by 35 states.

57 For text see U.N. Doc. E/CN.4/Sub.2/210. The convention entered into force on May 22, 1962.

In December, 1962, the General Conference of UNESCO adopted without dissont a Protocol instituting a Conciliation and Good Offices Commission to deal with disputes between states parties. The Commission is modeled on the Human Rights Committeo as contemplated in the Draft Covenant on Civil and Political Rights as adopted by tho Commission on Eluman Rights at its tenth session. The Protocol is contained in U.N. Doc. E/CN.4/Sub.2/228, Memorandum submitted by UNESCO to the Sub-Commission on Prevention of Discrimination and Protection of Minorities (Jan. 7, 1963).

58 For text see Sixth Report of the International Labour Organisation to the United Nations, Geneva, 1952, p. 160; 1951 Yearbook on Human Rights 469. As of June 10, 1962, the convention had been ratified or acceded to by 38 states.

50 For text see General Assembly, Res. 640 (VII), 7th Sess,, Official Records, Supp. No. 20 (A/2361), p. 28; 1952 Yearbook on Human Rights 375. As of June, 1962, tho convention had been ratified or acceded to by 36 states. See also Convention on tho Political Rights of Women. History and Commentary, ST/50A/27, U.N. Pub. Sales No. 1955.IV.17; The United Nations and the Status of Women, U.N. Pub. Sales No. 61.1.9.

60 For text see General Assembly, Res. 1040 (XI), Annex, 11th Sess., Official Records, Supp. No. 17 (A/3572), p. 18; 1957 Yearbook on Human Rights 301. As of Juno, 1062, the convention had been ratified or acceded to by 27 states. See also Nationality of Married Women, Doc. F/CN.6/254 and Addenda, U.N. Pub. Sales No. 1955.TV.1; Legal Status of Married Women, U.N. Pub. Sales No. 57.IV.8.

61 For text see General Assembly, Res. 1763 (XVII), 17th Sess., Official Records, Resolutions, Supp. No. 17 (A/5217), p. 28. Another convention which should perhaps be mentioned in connection with the status of women is the Convention for the Suppression of the Traffic of Persons and of the Exploitation of the Prostitution of Othorg, General Assembly, Res. 317 (IV), 4th Sess., Official Records, Resolutions, pp. 33-35 (1949).

62 For text of the declaration as drafted by the Commission on Human Rights and a note by the Secretary General reporting on the progress of its consideration by tho Third Committee of the General Assembly, see U.N. Doc. A/5145. At the 17th Session of the General Assembly the Third Committee revised and approved tho Proamble and Art. 1 of the Declaration. At the same session the Assembly decided to complete the drafting of this instrument at its 1963 session. See Report of the Third Committee, U.N. Doc. A/5359, and General Assembly Res. 1839 (XVII).

os For text of the declaration as submitted to the General Assembly in 1960 by the Economic and Social Council, see ECOSOC Res. 756 (XXIX). The Genernl Assembly 
on the Rights of the Child. ${ }^{\circ 4}$ All of these instruments are organic parts of the United Nations human rights program, and comprehensive review would give them detailed exposition and appraisal.

The most important measures yet projected in the fulfillment of the Charter provisions are, however, the two proposed Covenants, one on Civil and Political Rights and the other on Economic, Social, and Cultural Rights, ${ }^{\circ 5}$ designed as comprehensive definition in the form of treaty obligation of the principal human rights with respect to which Member states are today willing to permit and undertake appropriate international implementation. ${ }^{68}$ These Covenants, in one form or another, were studied and deliberated by the Human Rights Commission for some eight years until the final drafts were completed in 1954. In the same year they were submitted for approval to the Third Committee of the General Assembly, which has been considering them, article by article, since 1954, and to date has adopted, with numerous amendments, the preambles of both conventions, all the substantive articles of the Covenant on Economic, Social, and Cultural Rights, and all the substantive articles of the Covenant on Civil and Political Rights. ${ }^{67}$

has yet to consider the draft declaration. See also U.N. Docs. $A / 5363$ and $A / 5444$ (1963).

01 For text of the declaration see General Assembly, Res. 1386 (XIV), 14th Sess., Offieial Reeords, Resolutions, Supp. No. 16 (A/4354), p. 19, and U.N. Doc. A/4249. A survey of various declarations and draft declarations is offered in Schwelb, Human Rights and the International Community 59-72 (1964).

os For the full text of both draft Covenants as prepared by the Commission on Human Rights, see its Report of its Tenth Session to the Eeonomic and Social Council, 18th Sess., Official Records, Supp. No. 7 (U.N. Docs. E/2573; E/CN.4/705), pp. 62-72. For the text of the two draft covenants as revised by the Third Committee of the General Assembly at the 10th (1955) to 17th (1962) sessions, see U.N. Doc. A/C.3/ L.1062 (1963); for the text of the articles revised at the 18th session (1963), see the Report of the Third Committee, U.N. Doc. A/5655. For Secretariat annotations on the text of the draft covenants, see Doe. A/2929 (1955). For a general discussion of the provisions sce: Simsarian, "Eeonomic, Soeial, and Cultural Provisions in the Human Rights Corenant-Revision of the 1951 Session of the Commission on Human Rights," 24 Dept. of State Bulletin 1003-1014 (1951); Saba, "Les Droits économiques, sociaux, et eulturels dans le future Paete des Droits de l'homme," 78 Journal du Droit International 464-481 (1951); Ch. Malik, "Human Rights in the United Nations," 13 U.N. Bulletin 248-253 (1952); Simsarian, "Two Covenants of Human Rights Being Drafted," 27 Dept. of State Bulletin 20-23 (1952), and his "'Progress in Drafting Two Corenants on Human Rights in the United Nations," 46 A.J.I.I. 710-718 (1952).

"Holcombe, in "The Corenant on Human Rights," 14 Law and Contemporary Problems 413 (1949), offers this appraisal: "It is a project for a piece of international legislation, more ambitious and perhaps more important than any other in the history of international law."

or For the texts of the articles as adopted thus far by the Third Committee of the General Assembly, see: General Assembly, Third Committee, 10th Sess., Official Records, Report (A/3077); ibid., 11th Sess., Report, pp. 4-21 (A/3525); ibid., 12th Sess., Report, pp. 6-14 (A/3764 and Add. 1); ibid., 13th Sess., Report, pp. 4-13 (A/4045); ibid., 14th Sess., Report (A/4299); ibid., 15th Sess., Report, p. 10 (A/4625); ibid., 16 th Sess., Report, pp. 14-15 (A/5000); ibid., 17th Sess., Report (A/5365).

At the 1Sth Session of the General Assembly (1963) the Third Committee adopted 
The original plan was for a single Covenant on Human Rights, ${ }^{08}$ but in ordering two separate covenants the General Assembly recognized that there are many fundamental differences between traditional civil and political rights and the newly emerging claims to economic, social, and cultural benefits-differences in the degree of precision with which definitions and standards can be formulated, differences in appropriate modes of implementation, ranging from judicial enforcement and general legislation through many forms of community and private action, and differences in the resources available and time required for achievement of specified standards. ${ }^{69}$ Because of the central importance that these two Covenants, when completed and ratified, will have in the whole United Nations program, it may be worth while to subject to brief examination both the specific content of the preseriptions being proposed and the measures of enforcement or implementation being discussed.

\section{The Content of Proposed United Nations Prescriptions}

For concise and systematic summary and appraisal of the rights presently proposed for inclusion in the two Covenants, it may be helpful to outline the content of both Covenants, disregarding for this immediate purpose necessary differences in precision of formulation and modes of implementation, in terms of possible impact on the wide sharing of the basic values which were itemized at the beginning of this article for describing the growing, common demands of peoples around the globe and the objectives of all democratic government, national and international. It is, of course, recognized that, because of the interdependence of all values and institutional practices in a hierarchy of community processes, the various provisions in the Covenants may even in the short run affect more than one value and must in the long run affect all values. Summary in terms of the values principally and most immediately affected may, however, serve to highlight both the very broad scope of the new protection being proposed

Arts. 2 and 4 of the draft Covenant on Civil and Political Rights and decided to ingert an article on the rights of the ehild following Art. 22 of that Covenant. Tho Third Committee also adopted a provision on the right to freedom from hunger to bo addod as par. 2 of the combined Arts. 11 and 12 of the draft Covenant on Dconomic, Social and Cultural Rights (U.N. Doc. A/5655, Report of the Third Committee). See draft Covenants reprinted below, p. 857 .

68 General Assembly, Res. 421 (V) E, 5th Sess., Official Records, Resolutions, p. 43 (1950). The Soviet bloc throughout pressed for a single Covenant, Doc. E/ON.4/ SR. 269, p. 10; General Assembly, Third Committee, 6th Sess., Official Records, A/0.3/ SR. 368, p. 130. See also the statement of the delegate of Chile, Doc. B/CN.4/SR. 267, p. 7; Joint proposal of Chile, Egypt, Pakistan and Yugoslavia, Doc. A/C.3/L.182 (Nov. 30, 1951).

69 General Assembly, Res. 543 (VI), 6th Sess., Official Records, p. 36; Third Committee, 6th Sess., Official Records, Report, pp. 10-12 (A/1212). See also statemont of delegates of the United Kingdom (Docs. E/CN.4/SR.268, p. 4, and A/0.3/SR.361, p. 87), United States (Doc. A/C.3/SR.361, p. 78), France (Doc. A/C.3/SR. 363, p. 98), New Zealand (Doc. A/C.3/SR.367, p. 121), and Denmark (Doc. A/O.3/SR.362, p. 89); further, Doc. E/CN.4/529, pp. 13-16. 
for the individual human being and some surprising omissions of traditional rights. We proceed value by value, in the order listed at the beginning of the article. ${ }^{70}$

\section{Power}

An abundance of provisions in the Covenant on Civil and Political Rights, as might be expected, bear direetly upon the sharing of power. Article 6(1) precludes arbitrary deprivation of life, ${ }^{71}$ and Article 9(1) arbitrary arrest and detention. Article 12 seeks to establish freedom of movement ${ }^{72}$ and choice of residence within a state, freedom to leave and re-enter one's own country, as well as to leave another country, and freedom from arbitrary exile. Article 14 provides that all persons shall be equal before courts or tribunals and stipulates certain procedures for fair trials; ${ }^{73}$ Article 16 asserts that "everyone shall have the right to recognition everywhere as a person before the law"; and Article 24 establishes that "all persons are equal before the law" and that

the law shall prohibit any discrimination and guarantee to all persons equal and effective protection against discrimination on any ground

70 The summary we here make is basically in terms of the draft covenants as presented by the Commission on Human Rights in the Report of its Tenth Session to the Economic and Social Council, 18th Sess., Official Records, Supp. No. 7 (U.N. Does. $\mathrm{E} / 2573 ; \mathrm{E} / \mathrm{CN} .4 / 705)$, pp. 62-72 (1954). Any significant changes or additions made by the Third Committee of the General Assembly in adopting the articles will also be specified in the footnotes.

71 The Third Committee has made additions to Art. 6 which provide that sentence of death may not be imposed on people below 18 years of age, as well as on pregnant women, and that "nothing in this article shall be invoked to delay or to prevent the abolition of eapital punishment by any state party to the covenant." For amended text of Art. 6, see General Assembly, Third Committee, 12th Sess., Official Records, Report, p. 14 (A/3764 and Add. 1).

72 The British delegate doubted whether freedom of movement was a basic right (Doc. E/CN.4/SR.315, p. 5); the Australian delegate even moved for its deletion (ibid., p. 6); ". . . freedom of speeeh, the right of association, and human rights in general would be an illusion," asserted correctly the Indian delegate, "if the right to liberty of movement was not ensured." (Doc. E/CN.4/SR.315, p. 5.) The Third Committee amended Art. 12 so as to stipulate more clearly that "no one may be arbitrarily deprived of the right to enter his own country" and to provide that this right is not to be subject to any of the restrictions set forth in the article's first paragraph. For the amended text of Art. 12, see General Assembly, Third Committee, 14th Sess., Ofiicial Records, Report (A/4299).

73 For a justified eriticism of the ambiguity of the conception of a erime, see the comment of the delegates of Belgium (Doc. E/CN.4/SR. 310, p. 14) and of France (Doc. E/CN.4/L.182, p. 15). The amendments of the Third Committee to Art. 14 have added to the minimum guarantees to which an aceused is entitled the right "to communicate with counsel of his own ehoosing," the right "to be tried without undue delay," and the right "to be tried in his presence." The amendments also provide protection against doublo jeopardy, and guarantee convieted persons the right to revien of their convietions and sentences by a higher tribunal. For the amended text of Art. 14, see General Assembly, Third Committee, 14th Sess., Official Records, Report (A/4299). 
such as race, colour, sex, language, religion, political, or other opinion, national or social origin, property, birth, or other status. ${ }^{\text {.4 }}$

Article 3 adds a further understanding by the parties "to ensure the equal rights of men and women to the enjoyment of all civil and political rights set forth in this covenant." Article 23, moreover, significantly provides that "every citizen shall have the right and the opportunity," without irrelevant distinctions (specified in Article 2) and "without unreasonable restrictions," "to take part in the conduct of public affairs, directly or through freely chosen representatives," "to vote and be elected at genuino periodic elections held by universal suffrage and by secret ballot and guaranteeing the free expression of the will of the electors," and to have "access, on general terms of equality, to public service in the community." Article 15 seeks to prevent punishment for crimes retroactively declared. Article 19 offers protection for freedom of opinion and expression, Article 20, for freedom of peaceful assembly, and Article 21, for freedom of association. Article 13 prohibits the arbitrary expulsion of aliens. ${ }^{70}$

The provisions of the Covenant on Economic, Social and Cultural rights bear less directly on power, but Article 2(2), which imposes a guarantee that the rights enunciated in the Covenant "will be exercised without distinction of any kind," and Article 8, which undertakes to ensure "the free exercise of the right of everyone to form and join local, national, and international trade unions of his choice," 76 affect access to the bases of effective power in any community.

One perhaps unfortunate inclusion in both Covenants is the amorphous Article 1, on "self-determination," 77 which purports to give to "all peoples and all nations" the "right of self-determination, namely the right

74 Art. 24, as first drafted, established a general equality clause applicablo to all rights, and not merely to those recognized by the Covenants. See commonts of the delegates of Yugoslavia (Docs. E/CN.4/SR.326 and E/CN.4/SR.327, pp. 7-8), India (Doc. E/CN.4/SR.327, p. 4), and of Lebanon (Doc. E/CN.4/SR.327, p. 9). For moro recent developments, see note 81 below.

75 Cf. Art. 32 et seq. of the Convention on Refugees.

76 The Third Committee made significant amendments to Art. 8. Amended Par. 1 a includes the texts basically as originally proposed by the Human Rights Commission. Par. $1 \mathrm{~b}$ preserves the right of unions to form national federations or confederations and the latter to form international union organizations. Par. 1 c protects the right of unions to function freely, subject only to legal restrictions necessary "to national security and order or for protection of the rights of others." Par. 1 a socures the right to strike when done in conformity with the laws of the country. Par. 2 pormits "lawful restrictions" of these rights by the armed forces, police, or administration of a state. For the amended text of Art. 8, see General Assembly, Third Committeo, 11th Sess., Official Records, Report, pp. 11-12 (A/3525).

77 For criticism of the ambiguity of terms and the problems involved, see Nisot's statement (Doc. E/CN.4/SR.252). See also Secretary General's Memorandum: Tho Principle of Self-Determination in Relation to Chapters XI, XII, and XIII of tho Charter (Doc. E/CN.4/662, April 16, 1952); and his Note: The Right of Peoples and Nations to Self-Determination (Doc. E/CN.4/516, March 2, 1951). Art. 1 underwont considerable re-wording at the hands of the Third Committee. For the rovised text see General Assembly, Third Committee, 10th Sess., Official Records, Report (A/3077). 
freely ${ }^{78}$ to determine their political, economic, social and cultural status," 79 and adds that the "right of peoples to self-determination shall also include permanent sovereignty over their natural wealth and resources." In absence of a clear definition of peoples and of recognition that there are community responsibilities that transeend varying anachronistic indicia of "nations," deference to this vague doctrine ean do much harm to the cause of a world order in which individual freedoms are secure, and the appropriateness of including such a doctrine in a Covenant defining individual freedoms is highly questionable. ${ }^{80}$ It should also be noted that neither Covenant contains provisions, as did the Universal Declaration of Human Rights, for protection of nationality or freedom to change nationality, or for political asylum.

\section{Respect}

Provisions in the Covenant on Civil and Political Rights designed to promote respect for the inherent dignity of the human being are comprehensive in their range. Article 2(1) commits each ratifying state to ensuring "to all individuals within its territory and subject to its jurisdiction" the rights recognized in the Covenant "without distinction of any kind, such as race, colour, sex, language, religion, political or other opinion, national or social origin, property, birth, or other status," and, as indicated above, Article 24 prohibits "any discrimination" with respect to any rights, even those not embodied in the Covenant, on such grounds. ${ }^{.1}$ Article 25 guarantees to members of ethnic, religious, or linguistic minorities the right, in community with other members of their group, to enjoy their own culture, profess and practice their own religion, or to use their own language. Article 7 forbids torture, cruel and inhuman treatment or punishment, and involuntary medical or scientific experimentation. Article

78 Doc. E/CN.4/SR. 263, p. 4, comment of the French delegate stressing the democratic means by which the right to self-determination must be exereised.

79 Comment on the relationship between the right to self-determination and subversive activities and treason; see Doe. E/CN.4/SR.261, p. 8 .

so See relerant comments by Cassin (France) (Doc. E/CN.4/SR.253), by the delegates of the United Kingdom (Doc. A/C.3/SR.642), of The Netherlands (Docs. A/C.3/SR. 567, A/C.3/SR.642), of Canada (Does. A/C.3/SR.570, A/C.3/SR.645) and of Australia (Docs. A/C.3/SR.564, A/C.3/SR.647). See also Roosevelt, "The Universal Validity of Man's Right to Self-Determination," 27 Dept. of State Bulletin 917 (1952).

81 This provision underwent a fundamental change in the Third Committee, which inserted the words "In this respect" at the beginning of the second sentence of Art. 24, which now reads:

"All persons are equal before the law and are entitled without any discrimination to equal protection of the law. In this respect the law shall prohibit any diserimination and guarantee to all persons equal and effective protection. . . ."

As amended, the text does not prohibit all types of discrimination, particularly diserimination in private relations. The text as it now stands prohibits diserimination only in respect of the principle of equality before the law and in respect of equal protection of the law. The restrietive amendment was proposed by the United Kingdom and Greeee and adopted in a roll-eall vote of 36 to 30, with 11 abstentions. See Report of the Third Committee, 16th Sess., Doc. A/5000, pars. 105, 110 and 114. 
8 prohibits slavery, servitude, and forced or compulsory labor. Article 11 bars imprisonment "merely on the ground of inability to fulfill a contractual obligation." Articles 16 and 24 secure personality and equality before the law. Article 17 stipulates both against "arbitrary or unlawful interference" with "privacy, home, or correspondence" and "unlawful attacks" upon "honor and reputation," and requires the "protection of the law against such interference or attacks." Mention may be made also of requirements in Article 10 that "all persons deprived of their liberty shall be treated with humanity" and that "aceused persons shall be segregated from convicted persons." 82

The Covenant on Economic, Social and Cultural Rights contains, as indicated, a general guarantee of all rights enunciated in it "without distinction of any kind," and, in Article 3, a special undertaking "to ensure the equal right of men and women" to the enjoyment of all rights set forth in the Govenant.

\section{Enlightenment}

In the Covenant on Civil and Political Rights Article 19 provides that everyone shall have the rights "to hold opinions without interference" and to "freedom of expression," which latter right shall include "freedom to seek, receive and impart information and ideas of all kinds, regardless of frontiers" through all media. Article 18 includes "freedom of thought" among freedoms protected. ${ }^{83}$

The Covenant on Economic, Social and Cultural Rights offers more positive formulations. Article $14^{84}$ recognizes "the right of everyone to education" and to an education which will encourage "the full development of the human personality," strengthen "respect for human rights and freedoms," promote "maintenance of peace," and enable "all persons to participate effectively in a free society." Primary education is to be "compulsory and available free to all"; secondary education is to be

82 The Third Committee added to Art. 10 the provision that accused juvonilo persons be separated from adults, be brought as speedily as possible to trial, and bo accorded treatment appropriate to their age and legal status. For the amended text of Art. 10, see General Assembly, Third Committee, 13th Sess., Official Records, Report, p. 12 (A/4045).

83 The Third Committee added a paragraph to Art. 18 which provides for tho liberty of parents and legal guardians to ensure the religious and moral education of thoir children in conformity with their own convictions. For the amended text of Art. 18, see General Assembly, Third Committee, 15th Sess., Official Records, Report, p. 10 (A/4625).

84 The Third Committee added a provision to Art. 14 to the effect that "the devolopment of a system of schools at all levels shall be actively pursued, an adequate fellowslip system shall be established, and the material conditions of the teaching staff shall bo continuously improved." It also added a stipulation that no part of Art. 14 should be construed as interfering with the liberty of individuals and private bodies to establish educational institutions, subject to the principles of par. 1 and to the minimum standard of education of the state. For the amended text of Art. 14, see Genoral Assembly, Third Committee, 12th Sess., Official Records, Report, p. 6 (A/3764 and Add, 1), 
"generally available" and made "progressively free"; higher education is to be "equally accessible to all" and made "progressively free"; and fundamental education for all who have not completed primary education is to be "encouraged as far as possible." The freedom of parents to choose private schools is preserved. In Article 15 each state which has not achieved compulsory, free primary education undertakes "within two years, to work out and adopt a detailed plan of action for the progressive implementation" of the principle. ${ }^{85}$ Article 16 includes stipulations for "the right of everyone" to take part in cultural life and "to enjoy the benefits of scientific progress and its applications," for the taking of necessary steps "for the conservation, the development and the diffusion of science and culture," and for respecting "the freedom indispensable for scientific research and creative activity."

\section{Wealth}

In the Covenant on Economic, Social, and Cultural Rights, Article 6 recognizes the "fundamental right of everyone to the opportunity, if he so desires, to gain his living by work which he freely accepts," 87 and includes among the steps to be taken in implementing this right

programmes, policies and techniques to achieve steady economic development and full and productive employment under conditions safeguarding fundamental political and economic freedoms to the individual.

Article 7 requires, as one of the "just and favorable conditions of work," remuneration which provides "all workers as a minimum" with both "fair wages and equal remuneration for work of equal value ${ }^{88}$ without distinc-

85 It should be noted that Art. 15, providing for implementation of compulsory primary education, is the only article of the Covenant on Economic, Social and Cultural Rights which provides for a positive obligation accompanied by a precise time limit for its implementation. Doe. E/CN.4/SR.291, p. 9. See ibid., pp. 11, 13, 14.

86 The amendments made to Art. 16 by the Third Committee secured the right of everyone "to benefit from the protection of the moral and material interests resulting from any scientific, literary, or artistic production of which he is the author," and also provided that "the states parties to the Covenant recognize the benefits to be derived from the encouragement and development of international contacts and cooperation in the scientific and cultural fields." For the amended text of Art. 16, see General Assembly, Third Committee, 12th Sess., Official Records, Report, p. 10 (A/3764 and Add. 1).

87 The joint Yugoslav-Uruguayan draft proposal (Doc. E/CN.4/L.58/ Rev. 1), though stressing the element of freedom, suggested an explicit recognition of the right to work: "Everyone has the right to work: that is, everyone should be granted the right to obtain employment in order to earn his living by work which he freely accepts." As to the right of aliens to work, see the positive comments of delegates of the United States, Chile, and Greece (Doc. E/CN.4/SR.272). See also Commission on Fuman Rights, Activities of the United Nations and of the Specialized Agencies in the Field of Economic, Social, and Cultural Rights (Doc. E/CN.4/364/Rev. 1), p. 146, pars. 49-61 (1952).

$88 C f$. Yugoslavia's amendment (Doc. E/CN.4/L.63/Rev. 1) proposing to tie up "fair wages" with the cost of living and profits of the enterprises. 
tion of any kind," and "a decent living for themselves and their families." Article 8 protects

the free exercise of the right of everyone to form and join local, national and international trade unions of his choice for the protection of his economic and social interests.

The most obvious omissions are those of the right to own property and of protection against arbitrary deprivations of property. ${ }^{80}$ Article 17 of the Universal Declaration provides that "everyone has the right to own property alone as well as in association with others" and that "no one shall be arbitrarily deprived of his property." Some protection of individual elaims to resources may be necessary to protect other freedoms in a world of increasing governmentalization, centralization, concentration, and bureaucratization, and it should not be impossible to draft an article which would both protect the individual against arbitrary confiscation and yet permit community "nationalization" in appropriate instances..$^{90}$

\section{Well-Being (Safety, Health)}

Two articles in the Covenant on Civil and Political Rights stipulate certain minimal protections. Article 6 , as has been seen, protects against arbitrary deprivation of life, and imposes certain limits on capital punishment; ${ }^{91}$ and Article 7 prohibits torture, inhuman and degrading treatment or punishment, and medical or scientific experimentation without free consent.

In the Covenant on Economic, Social and Cultural Rights, Article 13 defines health as "a state of complete physical, mental and social wellbeing," recognizes "the right of everyone to the enjoyment of the highest attainable standard of health," and preseribes a definite series of steps to be taken to promote the full realization of this right. Article 7 stipulates for "safe and healthy working conditions" and for "rest, leisure and reasonable limitation of working hours and periodic holidays with pay." Article 10 seeks special protections for motherhood, children, and young persons." Article 11 recognizes "the right of everyone to adequate food,

89 Proposals of France (Doc. E/CN.4/L.66; comment, Doc. E/CN.4/SR.302); United States (Doc. W/CN.4/599), and Uruguay (Doc. E/CN.4/603). See, however, tho statement of the Chilean delegate (Doc. E/CN.4/SR.303, p. 3). See also the proposal of tho United States (Doc. E/CN.4/L.313), revised (Doc. E/CN.4/L.313/Rov. 1), the amendments to it proposed by Egypt, India, and Lebanon (Doc. E/CN.4/L. 316); the altornative proposal by Chile (Doc. E/CN.4/L.320/Corr. 1); and the text proposed by the sub. committee (Doc. E/CN.4/L. 321).

50 Nore recent attitudes in the United Nations are reflected in the General Aysombly Resolution of Dec. 14, 1962, on Permanent Sovereignty over Natural Resources. See Doc. A/RES/1803 (XVII); 57 A.J.I.L. 710 (1963).

91 Art. 6 in its early drafting explicitly applied an international standard, admitting capital punishment only if the laws imposing it are "not contrary to the principles of the Universal Declaration of Human Rights or the Convention on the Provention and Punishment of the Crime of Genocide." For recent changes, see General Assombly, 12th Sess., Report of Third Committee (U.N. Doc. A/3764), pars, 85, 102 and 120.

92 The Third Committee has added to Art. 10 the more precise stipulation that, 
clothing, and housing." 93 Artiele 9 adds a right to social security; and Artiele 12 generalizes a right "to an adequate standard of living and the continuous improvement of living conditions."

Skill

Many of the provisions concerning enlightenment bear equally upon skill. In the Covenant on Economic, Social and Cultural Rights, Article 14, with its detailed provisions for education, Article 16, with its emphasis upon the conservation, development, and diffusion of science and culture, and Article 8, protecting the right to form and join trade unions, are particularly relevant.

\section{Affection}

Article 10(3) of the Covenant on Economic, Social and Cultural Rights states that "the family, which is the basis of society, is entitled to the widest possible protection" and is "based on marriage, which must be entered into with the free consent of the intending spouses." Article 22 of the Covenant on Civil and Political Rights reiterates these points and adds that the right of men and women of marriageable age to marry and to found a family shall be recognized. It also requires the parties to direct their legislation "towards equality of rights and responsibilities for the spouses as to marriage, during marriage, and at its dissolution," and to lay down "social measures for the protection of any children" in cases of the dissolution of marriage.

\section{Rectitude}

Freedom of belief gets comprehensive protection in Article 18 of the Covenant on Civil and Political Rights. ${ }^{94}$ This establishes a right to "freedom of thought, conscience and religion" and provides that this right

shall include freedom to maintain or to change his religion or belief, and freedom, either individually or in community with others and in public or private, to manifest his religion or belief in worship, observance, practice and teaching.

It is added that "no one shall be subject to coercion which would impair his freedom to maintain or to change his religion or belief"' and that

freedom to manifest one's religion or beliefs may be subject only to such limitations as are prescribed by law and are necessary to protect

during a reasonable period before and after childbirth, mothers should be accorded paid leave from work or leave with adequate social security benefits. For that revised text of Art. 10, see General Assembly, Third Committee, 11th Sess., Official Records, Report, p. $17(\mathrm{~A} / 3525)$.

93 The Third Committee decided to amalgamate Arts. 11 and 12. The new combined article retained basically the same wording as the original two. For its text, see ibid., p. 19. At the 18th Session the Third Committee added a provision on the right to freedom from hunger to the combined Arts. 11 and 12. U.N. Doc. A/5655, Annex.

24 For the amendments made to Art. 18 by the Third Committee, see note 83 above. 
public safety, order, health, or morals or the fundamental rights and freedoms of others.

\section{Authorized Derogations}

It remains to mention certain provisions in the Covenant on Political and Civil Rights designed to permit a nation state under conditions of necessity to derogate from the high standards otherwise demanded by the Covenant. Article 4 provides that, in "time of public emergency which threatens the life of the nation and the existence of which is officially proclaimed," states

may take measures derogating from their obligations under this Covenant to the extent strictly required by the exigencies of the situation, provided that such measures are not inconsistent with other obligations under international law and do not involve discrimination solely on the ground of race, colour, sex, language, religion or social origin.

No derogations may be made from certain rights-such as those relating to protection from arbitrary deprivation of life and to freedom from torture, inhuman punishment, slavery, and so on-and a state "availing itself of the right of derogation" must "inform immediately the other states Parties to the Covenant through the intermediary of the Secretary-General, of the provisions from which it has derogated, the reasons by which it was actuated and the date on which it has terminated such derogation." Several articles contain, in addition, a general qualification that the rights they seek to protect may be limited, though only by law, in the interests of national security and public safety, order, health and morals. ${ }^{90}$ The possibility that these necessary provisions may be abused is obvious ${ }^{\circ 0}$ and probably avoidable only if comprehensive measures of international implementation are achieved.97

Throughout both Covenants runs explicit recognition that the protection of human rights is "the foundation of freedom, justice, and peace in the world," and taken in sum, despite all omissions and ambiguities, it is obvious that the two Covenants represent a most substantial achievement in prescribing, for implementation by appropriate national and international authority, both new protection for individual human rights and the general conditions of a free, peaceful, and abundant world society. ${ }^{98}$

\footnotetext{
95 These general qualifications are rather haphazardly itemized in the various articles. See Art. 12, Art. 18, par. 3, Art. 19, par. 3, Art. 20, Art. 21.

96 See comment of Malik (Lebanon), Doc. E/CN.4/SR.86, p. 13.

97 A less defendable derogation would have been established if one of the proposod federal-state clauses had been accepted. See proposal of Australia and India (Doc. E/ 2447, Annex II, Sec. B, No. III). It is difficult to see why one nation state should, because of peculiarities in internal constitutional structure (sometimes more allogod than real), seek or be allowed to assume lesser obligations with respect to human rights than other nation states. The Third Committee of the General Assembly has not jet considered Art. 27 of the Covenant on Economic, Social, and Cultural Rights or Art. 52 of the Corenant on Civil and Political Rights.

88 Certainly the completion and ratification of the two Covenants, as presently
} 


\section{Enforomanent Measures Proposed}

The most difficult problem still confronting the framers of the United Nations' human rights program is that of devising effective procedures for enforcement. Since the two Covenants are designed as treaty obligations and contain express promises by the parties to enact all necessary legislation and take other appropriate measures to secure the stipulated rights, any failures in performance that can be proved will of course make available to the other parties to the Covenants all the sanctions that are ordinarily available for violation of treaty obligation. ${ }^{\text {s9 }}$ The representatives of the Soviet Union and its satellites have contended from the beginning that no other measures of enforcement are needed or admissible, and that the establishment of any special international machinery for the implementation of human rights prescriptions would be an invasion of the "domestic jurisdiction" and "sovereignty" of nation states. ${ }^{100}$ The other Members of the United Nations have, however, rejected this argument and many proposals have been made for new machinery of implementation.

With respect to the Covenant on Economic, Social and Cultural Rights, early proposals reflected the general expectation that, since achievement is to be "progressive" over a period of time, implementation will be sought, not by complaints and hearings, but rather by an elaborate series of reports and comments, with performance being sanctioned by the attendant publicity. Provisions to this effect were included in Articles 17-25 of the draft Covenant as finally submitted for approval in 1954 by the Commission on Human Rights to the Third Committee of the General Assembly.

With respect to the Covenant on Civil and Political Rights, the proposals made involve a more radical break with traditional reliance upon the initiative of nation states, and include provision for complaints, investigation, hearings, and agreement to abide by decisions in particular instances of international authority. A brief survey of the various proposals reveals a gradual shift in attitude from emphasis upon negotiation and conciliation to more realistic conceptions which recognize the individual

proposed, by the nation states of the world could not rationally be construed to worsen such conditions. Both Covenants provide that no provision "may be interpreted as implying for any state, group or person any right to engage in any aetivity or perform any act aimed at the destruction of any of the rights and freedoms recognized herein or at their limitation to a greater extent than is provided for in this Covenant," and that there shall be "no restriction upon or derogation from any of the fundamental human rights recognized or existing in any contracting state pursuant to law, conventions, regulations or custom on the pretext that the present Covenant does not recognize such rights or that it recognizes them to a lesser extent." See Art. 5 of both Covenants.

90 Under the U.N. Charter, deprivations of human rights which amount to threats to peace may, of course, authorize invocation of a vast range of collective procedures. (See Arts. 10, 11, 14 and 39-42 of the Charter; also General Assembly Res. 377 (V) Uniting for Peace, 5th Sess., Official Records, Resolutions, p. 10 (1950); 45 A.J.I.L. Supp. 1 (1951).

100 Docs. A/C.3/SR.407, pp. 368, 372, 373; A/C.3/SR.394, p. 280; A/C.3/SR.565, p. 110. 
haman being as a formal "subject" of international law, as well as an effective participant in the world power process, and seek to confer upon him the competency effectively to claim his own rights. ${ }^{101}$

The most far-reaching of early proposals was made by Australia. This was submitted while the Universal Declaration of Human Rights was being formulated and was made in connection with the Paris Peace Conference of 1946 and the Peace Treaties of the Allied and Associated Powers with Bulgaria, Finland, Hungary, Italy, and Rumania. ${ }^{102}$ The proposal envisaged the protection of human rights by strictly judicial procedures, and sought to confer original and appellate jurisdiction on an international court in all disputes concerning the application and interpretation of the Universal Declaration, the Peace Treaties, and any other international treaties or conventions in the same field. ${ }^{103}$ It extended a right of access to the court not only to states but also to individuals and groups of individuals. The effectiveness of proceedings was to be guaranteed by a commitment of the states, parties to the undertaliing, to enforce orders or judgments by the court in favor of a complainant within their jurisdiction.

The United States Delegation, reacting to the Australian proposal, put forth a preliminary plan for implementation based on negotiations between states, with assistance from the Secretary General and from special small committees appointed by the Human Rights Commission to facilitate a settlement. ${ }^{104}$ This was followed up by a revised draft, submitted by the United States and the United Kingdom, ${ }^{105}$ which determined, among other things, a time limit for submission by accused states of observations in response to complaints, and offered details for replacing the proposed small committees by a Special Human Rights Committee.

A more elaborate joint proposal of France, India, the United Kingdom,

$10 x$ For general discussion, see MacChesney, "International Protection of Human Rights in the United Nations," 47 Northwestern U. Law Rev. 198-222 (1952); U.N. Secretary General, Memorandum, Draft International Covenant on Human Rights, Measures of Implementation, Does. E/CN.4/530 and E/CN.4/530, Add. 1 (March 16, 17, 1952). A particularly incisive analysis appears in Holcombe, "The Covenant on Human Rights,"' 14 Law and Contemporary Problems 413 (1949). See also the Becretary General's explanatory paper cited in note 27 above.

102 The original Australian proposal (Doc. E/CN.4/15, Teb. 5, 1947) suggested juris. diction of the proposed international court only in disputes concerning human rights and freedoms as formulated by the Declaration. For further discussion and argumonts, see Working Group on Implementation of the Commission on Human Rights, Roport (Doc. I/CN.4/53), pars. 25-33, 31-32; Annex $\mathrm{C}$ of the Report of the Second Session of the Commission on Human Rights, Doc. $E / 600$.

103 The original Australian proposal was further elaborated in Australia's Draft Statute of an International Court of Human Rights (Doc. E/CN.4/AC.1/27, May 10, 1948); see especially Art. 19. Cf. also the Secretary General's Note: International Court of Human Rights (Doc. Đ/CN.4/521).

104 Doc. E/CN.4/37 (Nov. 26, 1947).

105 Doc. E/CN.4/274; see, however, the French proposal (Doc. E/CN.4/82, Add. 10/ Rev. 1) suggesting a special committee competent also to receive petitions from indi. viduals and non-governmental organizations; for further elaboration, see Doc. IJ/ CN.4/147. 
and the United States, on May 9, 1950,106 strongly influenced the final form of certain draft proposals for measures of implementation tentatively agreed upon by the Human Rights Commission at its Sixth Session. These tentatively accepted proposals, which also appear in the final draft of the Covenant on Political and Civil Rights, establish a Human Rights Committee, composed of nine members to be selected by the International Court of Justice from a panel of specially qualified nominees, and authorize one ratifying state to invoke the good offices of the Committee against another ratifying state after the failure of prescribed direct negotiations as to an alleged violation of the Covenant. ${ }^{107}$ The Committee is empowered, "when available domestic remedies have been invoked and exhausted in the case," to "call upon the States concerned to supply any relevant information," to ask the Economic and Social Council to "request the International Court of Justice to give an advisory opinion on any legal question," and to "ascertain the facts and make available its good offices to the States concerned with a view to the friendly solution of the matter." The Committee is ordered to make a report, not later than eighteen months after receiving notice of violation, to the states concerned and to the Secretary General, for publication. If a solution is reached, the Committee is to confine its report "to a brief statement of the facts and of the solution reached." If a solution is not reached, the Committee shall state "its conclusions on the facts and attach thereto the statements made by the parties to the case." The powers of the Committee for investigation and for making recommendations are obviously most limited and the only sanction proposed is that of world opinion.

These tentative proposals, after their first formulation, were sharply rexiticized in many official and unofficial quarters for denying the right of complaint to individuals, groups of individuals, and various associations ; ${ }^{108}$ and, finally, during its Fifth Session, the General Assembly, in Resolution $421(V)$, proposed recognition of this right of individuals and associations, and requested the Economic and Social Council and the Human Rights Commission to draft appropriate provisions for insertion either in the Covenant itself or in a separate protocol.

The United States Delegation, in response to this resolution, proposed a separate protocol (later withdrawn), granting the Human Rights Committee jurisdiction to receive written petitions from individuals and certain non-governmental international associations. ${ }^{109}$ The Committee was

${ }^{1013}$ Doe. E/CN.4/474.

${ }_{107}$ Commission on Human Rights, Report of the Eighth Session, eited note 53 above, it $50-54$.

108 See, for instance, Doe. A/C.3/SR.406, pp. 361-362; Lauterpacht, note 1 above, p. 287; Cassin, "L'Homme, Sujet de Droit International et la Protection des Droits de l'Homme dans la Saciété Universelle," in La Technique et les Principes du Droit Public-Etudes en I'Honneur de G. Scelle 87 et seq. (1950).

For an historical surver of the right of petition on the international level, see U.N. Secretary General's Report: The Right of Petition (Doc. E/CN.4/419).

109 Doc. E/CN.4/557; see also draft proposals of Chile (Doc. A/C.3/L.81); Ethiopia 
to "determine which of the petitions received warrant detailed examination," and with respect to these it was to have substantially the same powers it has with respect to complaints from ratifying states.

For strengthening the protocol proposed by the United States, Uruguay offered an amendment, for which much can be said, creating an "office of the United Nations Attorney-General for Human Rights." 110 The proposed Attorney General would be entitled

to appear before the Human Rights Committee in connection with any case which, in his opinion, raises a problem of grave public interest, and to put to the Committee, either orally or in writing, the arguments in defense of such public interest.

He would also be empowered to "request the Committee to summon and hear witnesses and to ask for the communication" of relevant documents and to appear before the International Court of Justice in appropriate cases. $^{111}$

An earlier proposal by Uruguay, representing the greatest concessions yet offered from nation state sovereignty, would confer even greater powers upon a United Nations Attorney General (or High Commissioner) for Human Rights. ${ }^{112}$ According to this proposal, the Attorney General would be authorized, as part of a comprehensive and carefully worked out plan, to collect and examine all information relevant to the enforcement of human rights, to conduct, prior to any violation and with the consent of the state, studies and inquiries on the spot, and to initiate consultation with states concerned on situations likely to conflict with their commitments. With the occurrence of an alleged violation of human rights, he would be further authorized "to conduct an inquiry within the territory under the jurisdiction of the State Party concerned" and "to summon and hear witnesses and to call for the production of documents and other objects pertaining to the case."

The final proposal made in the Commission on Human Rights was introduced by France at the Tenth Session. It reflected the growing recognition in the Commission that a general unconditional provision on the right of petition was not likely to be approved at that time, and it thus sought at least to make some provision for the eventual realization of that right. The proposal stipulated that no provision in the Covenant

and France (Doc. A/C.3/L.78); Israel (Doc. A/C.3/L.91 (Dec. 1)); and Uruguny (Doc. $A / C .3 /$ L. 93).

110 Doc. E/CN.4/606/Rev. 1; see, however, U. S. objection, Doc. A/C.3/gR. 407, p. 369 ; also Doc. A/AC./3/564. For a comparative table of various proposals on measures of implementation and Protocol on Petitions, see Docs. E/CN.4/617 and Add. 1.

111 See also, howerer, the later proposal submitted jointly by Uruguay, Ohile, Egypt, and the Philippines (Does. E/CN.4/L.341 and E/CN.4/L.341/Rev, 1), which does not provide for an office of U.N. Attorney General, but does secure to individuals and organizations the right of petition.

112 Doc. E/CN.4/549. See also Commission on Human Rights, Report on its Tenth Session to the Economic and Social Council, 18th Sess., Official Records, Supp. No. 7 (U.N. Docs. E/2573; E/CN.4/705), pp. 74-76. 
shall prevent the Committee from dealing with any matter concerning the alleged violation of human rights by a State which is a party to international instruments other than the present Covenant, which recognize the competence of the Committee to examine complaints from the States Parties to the said instrument or from sources other than States. ${ }^{112}$

Of the various enforcement proposals briefly discussed, the least satisfactory one, which confines the proposed Human Rights Committee largely to the function of "good offices" between contending nation states, was, with a few changes, incorporated in Articles 27-48 of the draft Covenant as finally adopted by the Commission. The proposed Committee, deprived of the authority to receive petitions from individuals and from non-governmental organizations, could scarcely be expected to achieve an effective enforcement of human rights. In addition, the Commission, in Article 49, provided for a system of reports similar to that found in Articles 17-25 of the Covenant on Economie, Social, and Cultural Rights. The inclusion of Article 49 has been criticized by several delegates as detracting from the immediacy of the obligations which the Covenant imposed and as introducing an element of progressive application not appropriate in the Covenant on Civil and Political Rights. ${ }^{114}$

The Third Committee of the General Assembly has not yet had the opportunity to consider the enforcement articles drafted by the Commission on Human Rights. It is to be hoped that when it does so, amendments will be made to provide for the right of petition by individuals and nongovernmental organizations. When the draft Covenants were first submitted to the Third Committee in 1954 for preliminary, general discussion, the question of the right of petition was one of the most hotly debated. ${ }^{115}$ At that time, the delegate from Egypt made an especially incisive point when he remarked that:

It was also something of a paradox that nearly all the delegations which objected to the right of individual petition were those which were opposed to Article one of both draft covenants on the ground that it concerned a collective right; it would appear that the argument changed aecording to circumstances. ${ }^{116}$

It needs no emphasis that the difficulties inherent in the problem of enforcement will not be easily resolved. The establishment of effective procedures would mean substantial changes in the distribution of power between Member states and the United Nations, and, within Member states, between active decision-makers and the individual human being. Changes of such magnitude are seldom quickly achieved, as is further evidenced

113 Doe. E/CN.4/L.342/Rev. 1.

114 See, for example, the comment of the British delegate (Doc. A/C.3/SR.562, p. 96). 115 See, for example, the statements made by the delegates from the U.S.S.R. (Doc. A/C.3/SR.565, p. 10), India (Doc. A/C.3/SR.569, pp. 131-132), Sweden (Doc. A/C.3/ SR.571, p. 143), and Uruguay (Does. A/C.3/573, pp. 154-155, and A/C.3/SR.578, p. 179).

116 Doc. A/C.3/SR.571, p. 140. 
by the United States policy announced in 1953, that it does not intend to become a party to the proposed draft Covenants or to any other conventions on human rights. ${ }^{117}$ The maintenance of this position by one of the world's most powerful and influential nations has tended to diminish the enthusiasm and hopefulness with which delegates of other nations have approached the task of drafting the two Covenants ${ }^{118}$ and has resulted in the United States' relatively passive rôle in the discussion of the Covenants and its general policy of abstention from voting on the articles. ${ }^{119}$

It should be noted, however, that, simultaneously with this announcement, the United States delegates proposed to the Commission on Human Rights that it undertake three new major activities. ${ }^{120}$ This proposal was later adopted by resolutions of the Economic and Social Council ${ }^{121}$ and approved in part by the General Assembly, ${ }^{122}$ thus establishing three new programs, which have added a different and important dimension to the United Nations' work on human rights. ${ }^{123}$ The first of these provides for triennial reports by Member states to provide the Commission with information as to the progress achieved and the difficulties encountered

117 See statement by Secretary of State Dulles before the Senate Judiciary Committee, April 6, 1953, reprinted in Review of the United Nations Charter: A Collection of Documents, 83rd Cong., $2 \mathrm{~d}$ Sess., Senate Doc. No. 87 (Washington, Govornmont Printing Office, 1954), p. 295. See also New York Times, Jan. 24, 1954, p. 9.

118 See, for example, the statement of the Saudi Arabian delegate in 1054 (Doc. A/C.3/SR.563, p. 99). See also relevant comment in Gross, The United Nations: Structure for Peace 106 (1962).

119 See Does. E/CN.4/340, A/C.3/SR.646, p. 109, and E/CONF.24/BR.3.

Reference may now be made to: (a) the "Explanatory paper on measures of im. plementation" prepared by the Secretary General, U.N. Doc. A/5411, April 29, 1903, and (b) to the fact that the General Assembly, on the recommendation of the Third Committee, has adopted a resolution on implementation in which it, inter alia, reaffirms its belief that final adoption of the draft International Covenants on Fuman Rights is urgent and essential for the universal protection and promotion of human rights; requests the Secretary General to transmit to Member states the text of the articles which were adopted at the tenth to eighteenth sessions of the General Assombly, with related documents; and invites $\mathrm{N}$ [ember states to consider these texts and the measures of implementation elaborated by the Commission on Human Rights, in order that they may be in a position to decide on the measures of implementation and on the final clauses. The General Assembly also decided to make a special effort at its Nineteenth Session, i.e. in 1964, to complete the adoption of the entire text of the draft Covenants. 120 See letter of Secretary of State Dulles to U. S. representative on the Commission on Human Rights, April 3, 1953, reprinted in Review of the United Nations Charter: A Collection of Documents, eited note 117 above, p. 262. For text of U. S. proposals, see U.N. Doc. E/2447, pars. 263, 269, 271.

121 ECOSOC Res. 624/XXII/BI and II (1956).

122 General Assembly, Res. 729 (VIII), 730 (VIII), 839 (IX), and 926 (X).

123 For more comprehensive discussion of these new programs, see: Humplrey, "Euman Rights: New Directions in the Human Rights Program," Now York Law Forum 391 (1958); Higgins, "Technical Assistance for Human Rights," Tho World Today 174, 219 (1963); Lin Mousheng, note 41 above, at 107-118; United Nations Work for Human Rights, op. cit. note 1 above, at 25-30; Simsarian, "Fuman Rights Among Diverse World Orders," 1959 Proceedings, Am. Soc. Int. Law 245. 
in each country in the matter of human rights. The second program entails a series of comprehensive global studies of specific rights enumerated in the Universal Declaration of Human Rights. ${ }^{124}$ The third and perhaps most successful of the new programs established advisory services for the implementation of human rights. The services offered take essentially three different forms: the organization of seminars on various specific human rights; the provision of expert advice for countries which request aid in the solution of problems involving human rights; ${ }^{125}$ and provision of fellowships for responsible representatives of countries to visit other member countries for the purpose of studying the techniques used there for the protection of human rights. ${ }^{128}$ Of these, the organization of seminars for participation by representatives experienced in the subjects considered has been given the greatest emphasis. ${ }^{127}$ To date, eighteen such seminars have been held, ${ }^{128}$ and it has been the consensus of most participants and commentators that they provide a most valuable opportunity for expert representatives to exchange experiences and then use acquired insights to improve conditions in their own countries upon their return.

\section{Esperience in the Application of Human Rights Prinomles}

The experience of the United Nations thus far in securing application of its human rights principles offers little cause for optimism. Though its various organs have been courageous and consistent in asserting international concern and in denouncing notorious deprivations of human rights as violations of the Charter, offending nation states have-in the absence of effective enforcement procedures-paid little attention to the collective condemnations.

Two well-known instances of failure may be recalled: ${ }^{129}$

Although the question of the treatment of persons of Indian and Pakistani origin in South Africa has been before the General Assembly since 1946, and the whole racial situation in South Africa since 1952, and although the Security Council has also taken action in the matter, the grievances are still unredressed. ${ }^{130}$ A series of discussions, resolutions and

124 The first two studies undertaken by the subcommittee appointed for this purpose have been on "the right of everyone to be free from arbitrary arrest, detention and exile" and "the right of arrested persons to communicate with those whom it is necessary for them to consult in order to ensure their defense or to protect their essential interests." See United Nations Work for Human Rights, cited note 1 above, at 26-28. 125 See especially Higgins, loc. cit. note 123 above, at 220-221.

128 Ibid. 219-220.

127 Ibid. 221-223.

128 For a list of these seminars, their topies, dates and locations, see Iin Mrousheng, note 41 above, at 109-110.

120 For more detailed review, see Martin, "Fuman Rights and World Polities," 5 Yearbook of World Affairs 37, 62 (1951).

130 General Assembly, Res. 44 (I), 267 (III), 395 (V), 511 (VI); 'Assembly's Action on Question of Indians in South Africa," 13 U.N. Bulletin 587 (1952). See also more recently, General Assembly, Res. 1375 (XTV), 1598 (XV), 1881 (XVIII) and 1978 (XVIII); and Security Council, Docs. $\mathrm{S} / 4300$ (1960), S/5386 and $\$ / 5471$ (1963) 
recommendations do not seem to have shaken South Africa in her insistence that the matter is not of United Nations concern and in her resolution to continue the challenged practices.

The governments of Hungary, Bulgaria, and Rumania were accused by the Western Powers, parties to the Paris Peace Treaties of 1947, of having not lived up to their obligations in regard to human rights which they had undertaken in the treaties. The General Assembly repeatedly expressed its concern at the grave accusations made against the three states. ${ }^{131}$ Their governments refused, however, to co-operate even in the efforts to examine the charges, in spite of a ruling by the International Court of Justice that it was their treaty obligation to do so and to appoint their representatives to the Treaty Commissions which are competent to settle the disputes. $^{132}$

131 General Assembly, Res. 385 ( $\nabla)$, 5th Sess., Official Records, Resolutions, p. 17 (1950). Concerning the Hungarian Revolution specifically see: General Assembly, Res. 1004 (ES-II), 1005 (ES-II), 1006 (ES-II), 1007 (ES-II), 1008 (ES-II), 2nd Spec. Soss., Official Records, Resolutions (1956); and General Assembly, Res. 1127 (XI), 1128 (XI), 1129 (XI), 1130 (XI), 1131 (XI), 1132 (XI), 11th Sess., Official Records, Rosolutions (1956), pp. 63-64.

132 See Interpretation of Peace Treaties, Advisory Opinions, [1950] I.C.J. Rep. 65, 221 ; 44 A.J.I.I. 742,752 (1950).

Contrasting reference may now be made to the General Assembly's consideration of the item "The Violation of Human Rights in South Viet-Nam." During the consideration of this item at the 1232nd, 1234th and 1239th meetings of the General $\mathrm{As}$ sembly (October, 1963), the President read to the Assembly a letter from the Special Mission of South Viet-Nam extending an invitation to the representatives of sevornl Member states to visit South Viet-Nam in order that they might see for themsolves what the real situation was as regards relations between the Government and the Buddhist community of Viet-Nam. In the letter Viet-Nam invited the President to lend his good offices in helping to establish this mission. Later in the proceodings the President asked: "Am I to take it that the Assembly wishes to act in accordance with the aforesaid letter... ? Since there are no objections I shall do so. The debate on item 77 is therefore suspended."

Subsequently the President announced the appointment of the mission with Aunbassador Pazhwak of Afghanistan as chairman. Mr. Pazhwak was also the chairman of the Commission of Human Rights. The Principal Secretary of the Mission was the Director of the Division of Human Rights. The mission adopted its rules of procedure (Annex II, Doc. A/5630), which contained a Paragraph 12 reading as follows: "The Mission is an ad hoc fact-finding body and has been established to ascertain the facts of the situation as regards the alleged violations of human rights by tho Government of the Republic of Viet-Nam in its relations with the Buddhist community of that country." Paragraph 13 reads: "The Mission shall seek factual ovidenco. The Mission shall collect information, conduct on-the-spot investigations, recoivo petitions and hear witnesses. The impartiality of the Mission shall be demonstrated at all times."

The Mission reported to the General Assembly in a comprehensivo document, $A / 5630$, of Dec. 7, 1963. The coup d'état of Nor. 1, 1963, changed the situation fundamentally. As a consequence the General Assembly did not take any action on the report. Tho President announced on Dec. 13 (Doc. A/P.V. 1280) that he had been informed by tho sponsors of the item that "in the light of recent events that took place in Viet-Nam ... they do not think it useful to diseuss this item at this time." It was decided that no further action was required. 
With respect to non-self-governing and trust territories, the United Nations has had, in contrast, some opportunity to put its principles into practice. The approving of trusteeship agreements, ${ }^{133}$ the consideration of reports submitted by administering authorities, the examination of individual petitions, and the sending of missions into the territories, all offer opportunities for the exercise of control. ${ }^{134}$ The trusteeship agreement with Italy for the temporary administration of Somaliland, for example, prescribes that the administering authority accept the Universal Declaration "as a standard of achievement for the Territory." 135 It may be added, furthermore, that the principles of the Universal Declaration of Human Rights have already had a very considerable influence both upon the resolutions and recommendations of the General Assembly and upon many new prescriptions of formal authority in other arenas. ${ }^{130}$ On every appropriate occasion, whether concerned with general issues about Members' responsibilities for the promotion of human rights and maintenance of peace ${ }^{137}$ or with specific problems about freedom of information, ${ }^{138}$ diserimination against foreign labor, ${ }^{139}$ racial discrimination, ${ }^{140}$ the granting of independence to colonial countries, ${ }^{141}$ and so on, the General Assembly has invoked the Universal Declaration and its fundamental policies. Other important occasions which illustrate the widespread invocation of the Declaration's principles include the Caracas Conference of American States of $1954^{142}$ and the Bandung Conference of Asian-African States of 1955.143

133 Art. 85 of the Charter.

134 Art. 87 of the Charter. See also General Assembly, Res. $446(\nabla)$, Information on Human Rights in Non-Self-Governing Territories, 5th Sess., Official Reeords, Resolutions, p. 54 (1950); Res. 552 (VI), Examination of Petitions, ibid., 6th Sess., p. 55 (1951/52).

130 Art. 10 of the Declaration of Constitutional Principles of the Trusteeship Agreement for the Territory of Somaliland under Italian Administration, General Assembly, 5th Sess., Official Records, Supp. No. 10, p. 11 (A/1294). See also General Assembly, Res. $442(\nabla)$.

130 For more detailed analysis of the Declaration's influence, see Schwelb, "The Influence of the Universal Declaration of Human Rights on International and National Law,' 1959 Proceedings, Am. Soc. Int. Law 217; A Standard of Achievement, op. cit. note 1 above, at $24-30$.

137 Res. 250(IV) (6), Essentials of Peace, General Assembly, 4th Sess., Official Records, Resolutions, p. 13 (1949); Res. 540 (VI), General Assembly, 6th Sess., Official Records, Resolutions, p. 35 (1951/52).

138 General Assembly, Res. 424(V), ibia., 5th Sess., p. 44 (1950).

130 General Assembly, Res. 315 (IV), ibid., 4th Sess., p. 32 (1945).

140 General Assembly, Res. 324 (IV), ibid., p. 39 ; Res. 644 (VII), ibid., 7th Sess., p. 32 (1952).

141 General Assembly, Res. 1514 (XV), ibid., 15th Sess., Supp. No. 16 (A/4684), p. 66 (1960).

142 Resolutions of the Tenth Inter-Ameriean Conference at Caracas, Venezuela, Mareh 1-28, 1954, 1954 Yearbook on Human Rights 394; 48 A.J.I.I. Supp. 123 (1954).

143 Final Communiqué of the Asian-African Conference, Bandung, Indonesia, April 18-24, 1955, 1955 Yearbook on Human Rights 339. See also Charter of Organization of African Unity, Addis Ababa, May, 1963, reprinted below, p. 873. 
Even at a more formal level of authoritative prescription, the influence of the Declaration has been by no means negligible. The Special Statute for Trieste of $1954^{144}$ and the Franco-Tunisian Conventions of $1955^{145}$ incorporated the whole Declaration as part of their substantive law. The European Convention for the Protection of Human Rights and Fundamental Freedoms of 1950, which undoubtedly has set up the most advanced international system to date for the protection of human rights, reflects in its provisions the impact of the Universal Declaration. ${ }^{140}$ The Preamble of the Peace Treaty with Japan of 1951 declares Japan's intention "to strive to realize the objectives of the Universal Declaration of Human Rights." 147 It should be noted, moreover, that the preambles of many of the limited international conventions completed under the auspices of the United Nations and its specialized agencies ${ }^{148}$ either quote from, or expressly refer to, the principles of the Declaration. ${ }^{140}$

In more recent jears a number of declarations on various subjects, bearing upon human rights questions, have been adopted by the General Assembly. Two especially reflect the growing authoritative status of the Universal Declaration of 1948. The Declaration on the Granting of Independence to Colonial Countries and Peoples of Dec. 14, 1960, Res. 1514 (XV), includes a paragraph 7 , which reads:

"All States shall observe faithfully and strictly the provisions of the Charter of tho United Nations, the Universal Declaration of Human Rights and the present Declaration on the basis of equality...." (Italies supplied.)

The United Nations Declaration on the Elimination of All Forms of Racial Difcrimination of Nov. 20, 1963, Res. 1904 (XVIII), has an Articlo 11 which reads as follows:

"Every State shall promote respect for and observance of human rights and fundamental freedoms in accordance with the Charter of the United Nations, and shall fully and faithfully observe the provisions of the present Declaration, the Universal Declaration of Human Rights and the Declaration on the granting of independence to coloninl countries and peoples." (Italies supplied.)

144 See U.N. Docs. S/3301 and Add. 1, S/3305; 31 Dept. of State Bullotin 556 (1954); 1954 Yearbook on Human Rights 398-400. See also Schwelb, "Tho Trieste Settlement and Human Rights," 49 A.J.I.L. 240 (1955). See, however, Agnolloto v. Renko and Editoriale Stampa Triestina, Clunet (1962), p. 220.

145 See 1955 Yearbook on Human Rights 340, 342.

116 For reference to relevant literature on the European Convention, sce Schwolb, "International Conventions on Human Rights," 9 Int. and Comp. Law Q. 654, nt 655, note 2 (1960); Vols. I and IV of the Yearbook of the European Convention on Fumsn Rights; and Weil, The European Convention on Human Rights (Loiden, 1863); 57 A.J.I.L. 804 (1963). A recent significant instrument in this regard is tho Europonn Social Charter, signed at Turin, Oct. 18, 1961. See Security in Freedom: Tho Europonn Social Charter, Council of Europe Directorate of Information, Strasbourg, 1962.

In 1963 three protocols to the European Convention on Human Rights wore signed. See 58 A.J.I.工. 33I-336 (1964), and Schwelb, "Documentation on the Working of the European Human Rights Machinery," ibid. 442.

147 Conference for the Conclusion and Signature of the Treaty of Peace with Japan, Record of Proceedings, San Francisco, Sept. 4-8, 1951, p. 313 (Dept. of State Pub. 4392, Int. Org. and Conf. Ser. II, Far Eastern 3); 1951 Yearbook on Human Rights 489. 148 See p. 616 above.

149 For preliminary analysis of the significance of these preamble references, seo Schwelb, "The Influence of the Universal Declaration of Human Rights on International and National Law," 1959 Proceedings, Am. Soc. Int. Law 217, 220-222. 
The impact of the Declaration on the internal law of many states further reflects the broadening scope of its influence. Explicit reference is made to the Declaration in the Constitutions of such recently emerging states as the Republies of Guinea, ${ }^{150}$ Irory Coast, ${ }^{151}$ Dahomey, ${ }^{152}$ Gabon, ${ }^{153}$ Madagasear, ${ }^{154}$ Senegal, ${ }^{155}$ Mali, ${ }^{156}$ and Somalia. ${ }^{15 t}$ Not to be forgotten, moreover, are the Statute of Togoland under French Administration of $1956^{158}$ and the Statutes of the Cameroons of 1957 and $1959,{ }^{159}$ which stipulated that the laws of these territories must be in conformity with the Universal Declaration of Human Rights. The principles of the Declaration are also reflected, though not specifically referred to, in the new Constitutions of France and the Federal Republic of Germany, ${ }_{2}^{160}$ India, ${ }^{161}$ Libya, ${ }^{162}$ Eritrea, ${ }^{163}$ the United States of Indonesia, ${ }^{164}$ El Salvador, ${ }^{165}$ Costa Rica, Syria, Cameroun, the Central African Republic, Chad, Congo (Brazzaville), Mauritania, Niger, Sudan, Togo, and Upper Volta. ${ }^{168}$ In addition to this already impressive and rapidly growing list, the legislatures of Paraguay, ${ }^{167}$ Canada, ${ }^{108}$ Guatemala, ${ }^{160}$ Argentina, ${ }^{170}$ Bolivia, ${ }^{171}$ and Panama ${ }^{172}$ have enacted statutes which expressly refer to the Declaration as a standard of achievement. Finally, the Universal Declaration or its individual 90.

1:o See the preamble and Art. 10 of its Constitution, 1958 Yearbook on Human Rights

161 See the preamble of its Constitution, 1959, ibid. 186.

152 See the preamble of its Constitution, ibid. 83 .

163 See the preamble of its Constitution, ibid. 119.

154 See the preamble of its Constitution, ibid. 193.

15is See the preamble of its Constitution, ibid. 258.

150 See the preamble of its Constitution, ibid. 275.

157 See Art. 7 of its Constitution (1960).

158 See Journal Officiel de la République Française, Aug. 26, 1956, Deeree No. 56847; 1956 Yearbook on Human Rights 267-268.

150 See Journal Officiel de la République Française, April 18, 1957, Decree No. 57301; 1957 Yearbook on Human Rights 273-274; Ordinance No. 58-1375, Dec. 30, 1958; Annex II to the Report of the U.N. Visiting Mission to Trust Territories in West Africa, 1958, Doe. T/1427, Art. 5.

100 See diseussion in Schwelb, "The Influence of the Universal Declaration of Human Rights on International and National Law,' loc. cit. note 41 above, at 224-225, and "Die Kodifikationsarbeiten der Vereinten Nationen auf dem Gebiete der Mensehenrechte," loc. eit. ibid. at 40-42.

1011949 Yearbook on Human Rights 99-111.

1021951 ibid. 226.

$1631952 i b i d .62$.

1041949 ibid. 113-117. $\quad 1651950$ ibid. 245, 250.

100 See Lin Mousheng, note 41 above.

167 See Act No. 94 of July 5, 1951, 1951 Yearbook on Human Rights 281.

16s See Ontario Fair Employment Practices Act of 1951, ibid. 38, and Fair Accommodation Praetices Act of 1954, 1954 ibid. 44.

109 See $i b i d .121$.

170 See Legislative Decree No. 1664 of Oct. 22, 1955, 1955 Yearbook on Human Fights 5.

171 See Legislative Decree No. 3937 of Jan. 20, 1955, ibid. 18.

172 See Act No. 25 of Feb. 9, 1956, 1956 ibid. 184. 
articles have been cited as authoritative prescriptions in the judicial decisions of numerous courts, both national and international. ${ }^{173}$

\section{CONCLUSION}

As grand as is the vision which inspires the United Nations human rights program and as indispensable as such vision may be to the achievement of a free, peaceful, and abundant world society, it is improbable in the present world context of bipolarized and other bloc power and of imminent expectations of violence, that startling new progress can be quickly effected on a global scale either in the acceptance of new authoritative prescriptions about human rights or in the establishment of workable enforcement measures. The degree to which the Universal Declaration of Human Rights, with its broad prescriptions of the essential rights of a free society, has captured the loyalities and imagination of peoples and decision-makers offers, however, a certain opportunity. Persuasive argument has been made that the early decision that the existing Commission on Human Rights is not authorized ${ }^{17 s}$ to act upon specific complaints from individuals and groups not only is not required by the provisions of the United Nations Charter but is even in contravention of such provisions. ${ }^{170}$ This decision could be reversed by the General Assembly. The Commission on Human Rights might then hear some, or as many as possible, of the numerous complaints submitted to it each year, investigate the complaints to the extent it can or that the offending state will permit, and make recommendations in terms of the policies described in the Universal Declaration. ${ }^{176}$ The cumulative impact of a series of investigations and recommendations, publicized for the sanction of world opinion and any other sanctions that may eventually be made available, might not be wholly

173 For citation to and discussion of such decisions, see Schwelb, "The Influence of the Universal Declaration of Human Rights...," note 41 above, at 226-228, and A Standard of Achievement, note 1 above, at 28-30.

An especially interesting decision is that in the case of Soc. Roy Export ot Oharlio Chaplin c. Soc. Le Film Rayee Richebs by the Court of Appeal in Paris, 87 Journal du Droit International 129-137 (1960). Considering the scope of application of tho Goneva Universal Convention on Copyright, the Court of Appeal stated on page 137:

"Whereas, in fact, a foreigner being assimilated to a citizen, by virtue of tho Genova Convention, he is entitled to the same right in France as a French author and there is no valid reason, even on the grounds of want of reciprocity, for limiting this assimilation to the financial protection of Copyright;

"Whereas, moreover, the Universal Declaration of Human Rights, voted by the Assembly of the United Nations on December 10th, 1948 and published in the Journal officiel on 19 February 1949, which gives it the force of French law, stipulates in Article 17 that . . ." [Emphasis added.]

174 Economic and Social Council, Res. 75 ( $\nabla$ ), Fifth Sess., Resolutions, p. 20 (1947); Res. 728/F/XXVIII (1959).

$175 \mathrm{~A}$ full statement of this interpretation appears in Lauterpacht, noto 1 abovo, at 223-233.

178 Commission on Human Rights, Report of the Eighth Session, note 53 abovo, at 42 , par. 292. 
without effect, and certainly such activity could serve only to enhance the loyalities of freedom-demanding peoples to the Organization. ${ }^{17 \tau}$

Similarly, though the prospects for effective promotion of human rights on a global scale are dim, the very factors that cause these prospects to be dim make imperative even more intensified efforts on half-world and regional bases by peoples who cherish the values of a free, peaceful, and abundant world society. The clarification to the peoples of the world of what such society may mean in contrast with totalitarian oppression, and the continued demonstration that all rational efforts are being made to establish and maintain such a society, are indispensable from sheer power perspectives. Such clarification and demonstration are necessary to sustain peoples' hopes and expectations that such society can be established and maintained despite all the forces against it, to fortify their beliefs that they can best maximize their own personal values in such society, to cement their loyalties to such society and to further the increasing identifications of all free peoples with each other, and, in sum to maintain that continuing consensus about goals and means which will promote the most effective political co-operation. It is for this reason that the Western democracies and peoples of similar values should bring new enthusiasms and energies, rather than timid hesitation, to the task of improving, completing, and ratifying the proposed Covenants on Human Rights. Though the free peoples may not be able immediately to achieve universality in the acceptance and application of their human rights principles, they can, by perfecting and promulgating their statement of these principles as authoritative community goals within the areas accessible to them, assume a potentially world-encompassing moral leadership about which they can build the power indispensable to survival.

177 The Chieago lawyer who proposed an international writ of habeas corpus for the release of William Oatis could be prophetic of rational future development. See 98 Cong. Rec., 82nd Cong., 2nd Sess., 5034 (May 8, 1952). In this regard, see also Kutner, World Habeas Corpus (2nd ed., 1962); “The Case for an International Writ of Habeas Corpus: A Reply,' 37 U. Detroit Law J. 605 (1960); Kutner and Carl, "International Writ of Habeas Corpus: Protection of Personal Liberty in a World of Diverse Systems of Public Order," 22 U. Pittsburgh Law Rev, 469 (1961). 